\title{
Host-guest Complexation between Cyclodextrins and Hybrid Hexavanadates: What are the Driving Forces?
}

\author{
Ibrahima Fa Bamba, ${ }^{[a, b]}$ Clément Falaise, ${ }^{[a] *}$ Jérôme Marrot,${ }^{[a]}$ Patrick Atheba,${ }^{[c]}$ Gildas Gbassi, ${ }^{[b]}$ David \\ Landy, ${ }^{[\mathrm{d}]}$ William Shepard, ${ }^{\left[{ }^{[e]}\right.}$ Mohamed Haouas, ${ }^{[\mathrm{a}]}$ and Emmanuel Cadot ${ }^{[\mathrm{a}] *}$
}

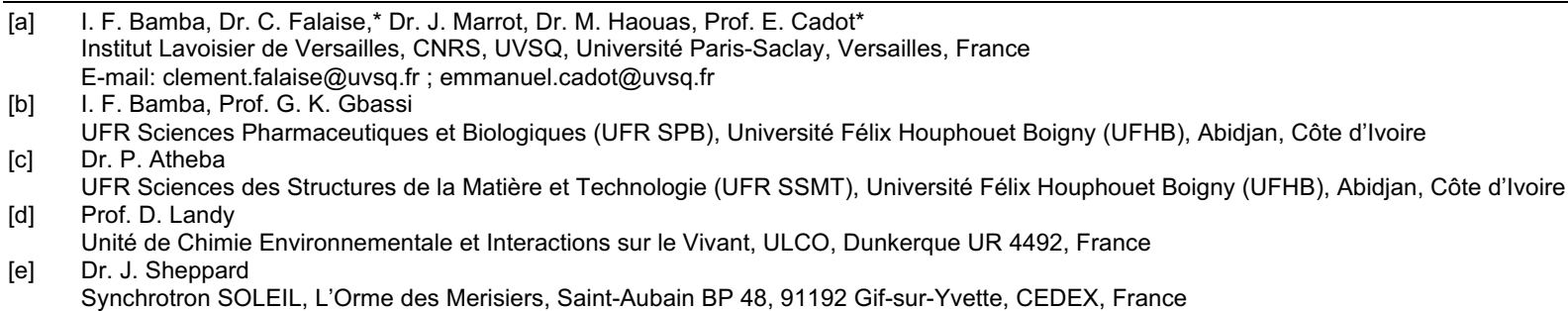

Supporting information for this article is given via a link at the end of the document.

\begin{abstract}
Host-guest complexes between native cyclodextrins ( $\alpha-, \beta-$ and $\gamma-C D$ ) and hybrid Lindqvist-type polyoxovanadates (POVs) $\left[\mathrm{V}_{6} \mathrm{O}_{13}\left(\left(\mathrm{OCH}_{2}\right)_{3} \mathrm{C}-\mathrm{R}\right)_{2}\right]^{2-}$ with $\mathrm{R}=\mathrm{CH}_{2} \mathrm{CH}_{3}, \mathrm{NO}_{2}, \mathrm{CH}_{2} \mathrm{OH}$ and $\mathrm{NH}(\mathrm{BOC})$ $(B O C=N$-tert-butoxycarbonyl) were studied in aqueous solution. Six crystal structures determined by single-crystal $X$-ray diffraction analysis revealed the nature of the functional $R$ group strongly influences the host-guest conformation and also the crystal packing. In all systems isolated in the solid-state, the organic groups $R$ are embedded within the cyclodextrin cavities, involving only a few weak supramolecular contacts. The interaction between hybrid POVs and the macrocyclic organic hosts have been deeply studied in solution using ITC, cyclic voltammetry and NMR methods $\left(1 D^{1} \mathrm{H} N M R\right.$, and $2 D$ DOSY, and ROESY). This set of complementary techniques provides clear insights about the strength of interactions and the binding host-guest modes occurring in aqueous solution, highlighting a dramatic influence of the functional group $R$ on the supramolecular properties of the hexavanadate polyoxoanions (association constant $K_{1: 1}$ vary from 0 to $2000 \mathrm{M}^{-1}$ ) while isolated functional organic groups exhibit only very weak intrinsic affinity with $C D$ s. Electrochemical and calorimetric investigations suggest that the driving force of the hostguest association involving larger $C D s(\beta$ - and $\gamma-C D)$ is mainly related to the chaotropic effect. In contrast, the hydrophobic effect supported by weak attractive forces appears as the main contributor for the formation of $\alpha-C D$-containing host-guest complexes. In any cases, the origin of driving forces is clearly related to the ability of the macrocyclic host to desolvate the exposed moieties of the hybrid POVs.
\end{abstract}

\section{Introduction}

Polyoxometalates (POMs) represent a class of well-defined anionic molecular oxides mostly built from elements of group $V$ $\left(\mathrm{V}^{5+}, \mathrm{Nb}^{5+}\right.$, and $\left.\mathrm{Ta}^{5+}\right)$ and $\mathrm{VI}\left(\mathrm{Mo}^{6+}, \mathrm{W}^{6+}\right)$ in their highest oxidation states, and exhibit striking catalytic or redox properties making them appealing components for designing nanostructured systems. ${ }^{[1]}$ In this context, the investigation of the non-covalent interactions of POMs with organic matter (macrocycles, surfactants, polymers, proteins, etc.) is of great interest for both fundamental knowledge and various applications in many fields including medicine and materials science. ${ }^{[2]}$ Among the commercially available organic building units, cyclodextrins (CDs) as natural amphiphilic macrocyclic polysaccharides are particularly useful to develop host-guest systems with POMs, offering the possibility to design self-healing, stimuli-responsive, catalytic or energy-related systems. ${ }^{[3-9]}$

The inclusion complexes involving $\mathrm{CDs}$ and POMs can be roughly divided in two families. In one hand, hybrid POMs with grafted organic ligands can exhibit high affinity towards hydrophobic hosting cavity. ${ }^{[3,7,8,10-13]}$ The main contributor of the supramolecular association in such systems has been found to be the "hydrophobic effect" supported by van der Waals forces, weak hydrogen bonding and steric effects. On the other side, purely inorganic POMs with low charge density, including Lindqvist $\left[\mathrm{M}_{6} \mathrm{O}_{19}\right]^{2-}$, Keggin $\left[\mathrm{XM}_{12} \mathrm{O}_{40}\right]^{3 / 4-}(\mathrm{M}=\mathrm{Mo}$ or $\mathrm{W}$, and $\mathrm{X}=\mathrm{P}$ or $\mathrm{Si}$ ), Dawson $\left[\mathrm{P}_{2} \mathrm{~W}_{18} \mathrm{O}_{62}\right]^{6-}$ or giant Mo blue wheel $\left\{\mathrm{Mo}_{154}\right\}$, showed extremely high ability to form supramolecular aggregates with CDs induced by the "chaotropic effect". ${ }^{[14-20]}$ These chaotropic POM units act as water-structure breakers, that leads to high energy hydration shell. It is worth to note that the chaotropic binding by CDs is not limited to POMs since this selfassembly process is also observed on other nanosized inorganic ions such as octahedral metal-atom clusters or dodecaborates. ${ }^{[21-}$ 28]

Recent progresses in polyoxovanadates (POVs) chemistry demonstrate their potential interest for energy-related applications including small molecules activation, redox-flow or Liand Na-ion batteries. ${ }^{[29-33]}$ Thank to their striking redox properties, POVs have been identified as appealing components for designing advanced materials such as resistive switching devices. ${ }^{[34,35]}$ POVs are also recognized for their relevant biological effects, as illustrated by numerous investigations about their interactions with enzymes, proteins or biological cells. ${ }^{[36-41]}$ While POVs are promising agents for applications in medicine, their interactions with macrocyclic drug carriers, such as cyclodextrins, have been reported only rarely. ${ }^{[42]}$ The interactions of POVs with CDs are usually weak, probably because of the high charge density of such anions by comparison to Mo- and Wcontaining POMs. ${ }^{[1]}$ In one hand, functionalization of POVs with organic moieties will reduce their overall charge but in other hand, allows to tune the hydrophilicity/hydrophobicity of their exposed surface and thus make them more prone to react with CDs. Herein, we prepared a series of Lindqvist-type POVs grafted with tris(hydroxymethyl)methane-derived ligands, $\left(\mathrm{HOCH}_{2}\right)_{3} \mathrm{C}-\mathrm{R}$ with 
$\mathrm{R}=\mathrm{CH}_{2} \mathrm{CH}_{3}, \mathrm{NO}_{2}, \mathrm{CH}_{2} \mathrm{OH}$ and $\mathrm{NH}(\mathrm{BOC})(\mathrm{BOC}=\mathrm{N}$-tertbutoxycarbonyl), and studied the host-guest encapsulation of the obtained hybrid Lindqvist-type POVs $\left[\mathrm{V}_{6} \mathrm{O}_{13}\left(\left(\mathrm{OCH}_{2}\right)_{3} \mathrm{C}-\mathrm{R}\right)_{2}\right]^{2-}$ (notated $\left.\mathrm{V}_{6}-(\mathrm{R})_{2}\right)$ with native cyclodextrins of various sizes, constituted of six ( $\alpha-C D)$, seven $(\beta-C D)$ or eight $(\gamma-C D)$ glucopyranoside units (Figure 1 ).
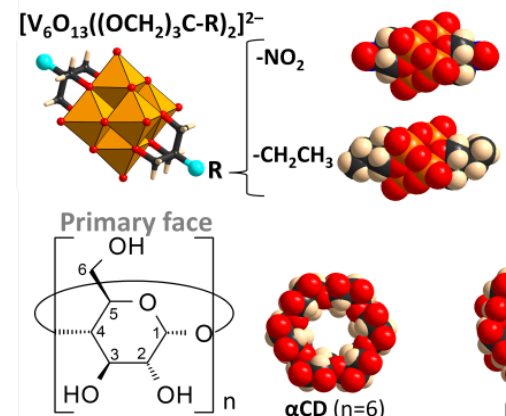

$-\mathrm{CH}_{2} \mathrm{OH}$

$-\mathrm{NH}(\mathrm{BOC})$
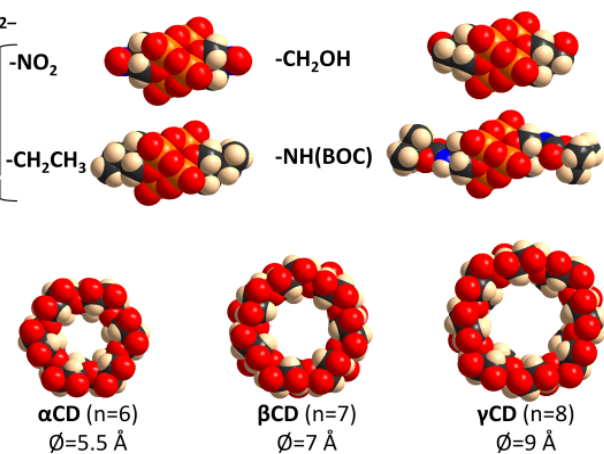

Secondary face

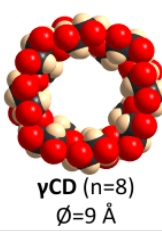

Figure 1. Structural representations of the molecular entities involved in this study. (Top) Polyhedral and space-filling representation of the Lindqvist type derivatives, $\left[\mathrm{V}_{6} \mathrm{O}_{13}\left(\left(\mathrm{OCH}_{2}\right)_{3} \mathrm{C}-\mathrm{R}\right)_{2}\right]^{2-}$, with the different functional $\mathrm{R}$ groups. This hybrid $\mathrm{POM}$ is built from six vanadium centers forming an octahedron and two trialkoxo ligands occupying the opposite faces of the octahedron. (Bottom) Schematic and space-filling representations of the toroidal cyclodextrin hosts that result from the condensation of $n$ glucopyranose units. The cavity size of $\alpha-C D, \beta-C D$ and $\mathrm{Y}-\mathrm{CD}$ is about $5.5,7.0$ and $9.0 \AA$, respectively. Color code: orange $=\mathrm{V}$, black $=\mathrm{C}$, red $=\mathrm{O}$, blue $=\mathrm{N}, \tan =\mathrm{H}$.

The non-covalent interactions between hybrid POVs and native $C D$ hosts have been investigated in aqueous solution using NMR methodologies, including ${ }^{1} \mathrm{H}$ NMR titration, ${ }^{1} \mathrm{H}$ DOSY, and ${ }^{1} \mathrm{H}$ ROESY. These experiments demonstrated the ability of hybrid Lindqvist POVs to form in solution various host-guest complexes with CDs wherein the interacting mode depends on the size of macrocycles and on the nature of the functional $R$ group. Crystallization attempts allow to isolate six host-guest complexes: $\left.\left[\mathrm{V}_{6} \mathrm{O}_{13}\left(\left(\mathrm{OCH}_{2}\right)_{3} \mathrm{C}-\mathrm{NO}_{2}\right)_{2}\right] @ \alpha-\mathrm{CD}\right\}^{2-}, \quad\left[\mathrm{V}_{6} \mathrm{O}_{13}\left(\left(\mathrm{OCH}_{2}\right)_{3} \mathrm{C}-\mathrm{NO}_{2}\right)_{2}\right] @ \beta-$ $\left.\mathrm{CD}^{2-}, \quad\left[\mathrm{V}_{6} \mathrm{O}_{13}\left(\left(\mathrm{OCH}_{2}\right)_{3} \mathrm{C}-\mathrm{NO}_{2}\right)_{2}\right] @ 2 \mathrm{\gamma}-\mathrm{CD}\right\}^{2-}, \quad\left[\mathrm{V}_{6} \mathrm{O}_{13}\left(\left(\mathrm{OCH}_{2}\right)_{3} \mathrm{C}-\right.\right.$ $\left.\left.\left.\left.\mathrm{CH}_{2} \mathrm{OH}\right)_{2}\right] @ 2 \beta-\mathrm{CD}\right\}^{2-},\left[\mathrm{V}_{6} \mathrm{O}_{13}\left(\left(\mathrm{OCH}_{2}\right)_{3} \mathrm{C}-\mathrm{CH}_{2} \mathrm{OH}\right)_{2}\right] @ 2 \gamma-\mathrm{CD}\right\}^{2}$, and $\left.\left[\mathrm{V}_{6} \mathrm{O}_{13}\left(\left(\mathrm{OCH}_{2}\right)_{3} \mathrm{C}-\mathrm{NH}(\mathrm{BOC})\right)_{2}\right] @ 2 \beta-\mathrm{CD}\right\}^{2-}$. The single-crystal analysis revealed that the interactions observed as short contacts in the solid-state are consistent with those observed in solution by NMR. At last, the driving forces arising from the host-guest recognition process between Lindqvist-type POVs and CDs, as well as their related binding modes and constants, are discussed in the light of NMR, isothermal titration calorimetry (ITC), and electrochemical investigations.

\section{Results and Discussion}

\section{Single-crystal $X$-ray diffraction.}

All crystallized compounds have been isolated from aqueous solution containing native cyclodextrin and hybrid hexavanadate. Details about the preparation of the precursors and the crystals formation are given in the experimental part.

$\left\{\mathbf{V}_{6}\left(\mathrm{NO}_{2}\right)_{2}\right\} @ \mathbf{\alpha}-\mathbf{C D}$. The compound $\mathrm{Na}_{2}\left[\mathrm{~V}_{6} \mathrm{O}_{13}\left(\left(\mathrm{OCH}_{2}\right)_{3} \mathrm{C}\right.\right.$ $\left.\left.\mathrm{NO}_{2}\right)_{2}\right] @\left[\left(\mathrm{C}_{6} \mathrm{H}_{10} \mathrm{O}_{5}\right)_{6}\right] \cdot 8 \mathrm{H}_{2} \mathrm{O}$ crystallizes in the noncentrosymmetric space group $P 21$ and the asymmetric unit cell contains one polyoxoanion and one alpha-cyclodextrin. The POV unit $\left[\mathrm{V}_{6} \mathrm{O}_{13}\left(\left(\mathrm{OCH}_{2}\right)_{3} \mathrm{C}-\mathrm{NO}_{2}\right)_{2}\right]^{2-}$ and $\mathrm{a}-\mathrm{CD}$ form infinite supramolecular 1D chains, $\left\{\left[\mathrm{V}_{6} \mathrm{O}_{13}\left(\left(\mathrm{OCH}_{2}\right)_{3} \mathrm{C}-\mathrm{NO}_{2}\right)_{2}\right] @ \alpha-\mathrm{CD}\right\}_{n}{ }^{2 \mathrm{n}}$, in which $\mathrm{a}-\mathrm{CD}$ acts as a ditopic supramolecular bridging unit (Figure $2 \mathrm{~A}-\mathrm{C}$ ). One $-\mathrm{NO}_{2}$ group of the POV interacts with the secondary face of $\alpha-C D$ and appears deeply embedded within the host cavity (Figure 2A), involving numerous weak interactions including six short contacts between hydrogen atoms of the methylene groups of the hybrid guest and the inner hydrogen atoms labeled $\mathrm{H} 3\left(\mathrm{~d}_{\mathrm{H} \cdots H}=2.1-2.4 \AA\right)$ and three short contacts between the oxygen atoms of the nitro group and the inner hydrogen atoms labeled $\mathrm{H} 5$ (do $\cdots \mathrm{H}=2.6-2.7 \AA$ ) (see Figure 1 for $\mathrm{H}$ labelling). The other $-\mathrm{NO}_{2}$ group of the hybrid polyoxoanion weakly interacts with the primary face of another $\alpha-C D$ (Figure 2B) through two short contacts between the oxygen atoms of the nitro group and hydrogen atoms $\mathrm{H} 6$ and $\mathrm{H} 5\left(\mathrm{do}_{\mathrm{O}} \mathrm{H}_{\mathrm{H}}=2.7 \AA\right)$. It results a 1D chain along the $b$ axis which is stacked to three other chains with a shift of $b / 2$ from one to the other (Figure 2C). Within this infinite chain, the shortest distance between two nitro groups belonging to adjacent POVs is about $3.5 \AA$. Within the infinite chain, the organic macrocycle does not cover the surface of the inorganic core of POV but interacts
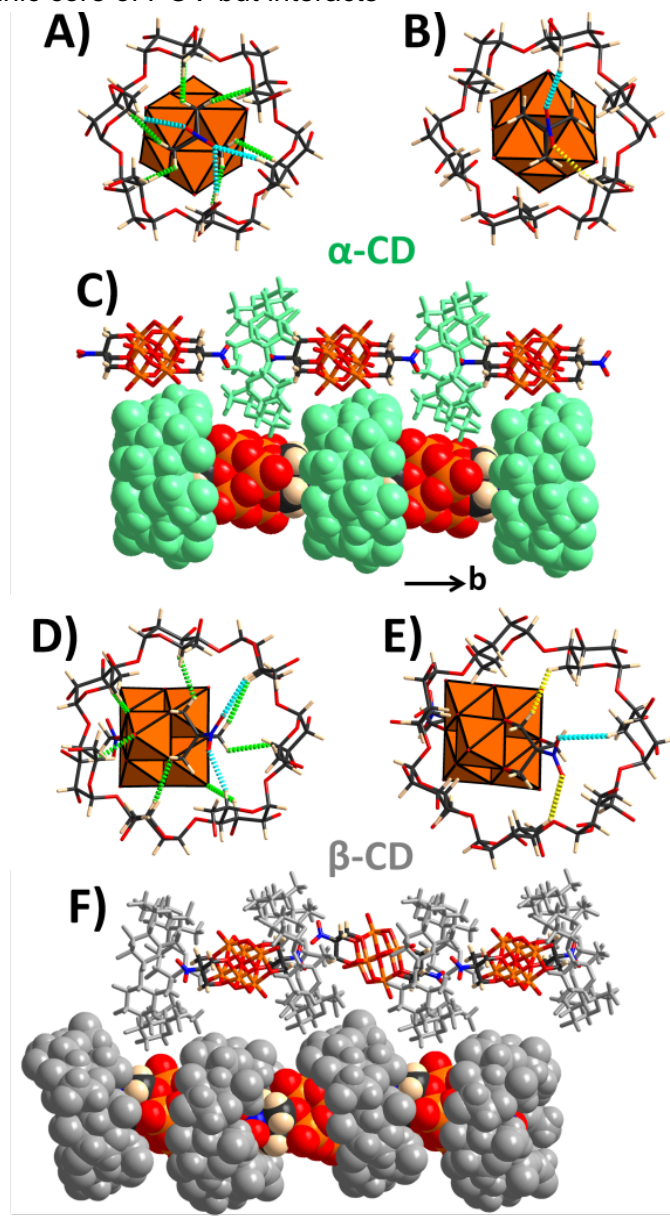

Figure 2. Mixed representations of crystal structures of $\left\{\mathbf{V}_{\mathbf{6}}\left(\mathrm{NO}_{2}\right)_{2}\right\} @ \mathbf{\alpha}-\mathbf{C D}$ and $\left\{\mathbf{V}_{6}\left(\mathbf{N O}_{2}\right)_{2}\right\} @ \beta-C D$. Views of the interaction between $\left[\mathrm{V}_{6} \mathrm{O}_{13}\left(\left(\mathrm{OCH}_{2}\right)_{3} \mathrm{C}-\mathrm{NO}_{2}\right)_{2}\right]^{2-}$ with the secondary face $(\mathrm{A})$ and the primary face $(B)$ of $\alpha-C D$, showing the short contacts between $H 3$ (dashed green line), $\mathrm{H} 5$ (dashed cyan line) and $\mathrm{H} 6$ (dashed yellow line) with the POV unit. The structural arrangement of $\left\{\mathbf{V}_{\mathbf{6}}\left(\mathrm{NO}_{2}\right)_{2}\right\} @ \mathbf{\alpha}-\mathbf{C D}$ can be described as infinite supramolecular hybrid chains $\left\{\left[\mathrm{V}_{6} \mathrm{O}_{13}\left(\left(\mathrm{OCH}_{2}\right)_{3} \mathrm{C}-\mathrm{NO}_{2}\right)_{2}\right] @ \alpha-C D\right\}_{n}{ }^{2 n-}$ (C). Illustrations of the short contacts between the nitro-functionalized hexavanadate and the secondary face (D) and the primary face (E) of $\beta$ $C D$. View of crystal packing highlighting the slight distortions of the infinite chain $\left\{\left[\mathrm{V}_{6} \mathrm{O}_{13}\left(\left(\mathrm{OCH}_{2}\right)_{3} \mathrm{C}-\mathrm{NO}_{2}\right)_{2}\right] @ \beta-\mathrm{CD}\right\}_{n}{ }^{2 n-}$. 
insured by the presence of sodium cations interacting with oxygen atoms of CDs and located quite far from the anionic mainly with the exposed functional group $-\mathrm{NO}_{2}$ as shown on space filling representation (Figure $2 \mathrm{C}$ ). The charge balance is POV anions (shortest distance is about $4.5 \AA$ ). The $\mathrm{Na}^{+}$cations also contribute to the 3D cohesion by linking the rims of adjacent $\alpha-C D$ hosts. Xray diffraction analysis also revealed the presence of free water molecules between the supramolecular chains.
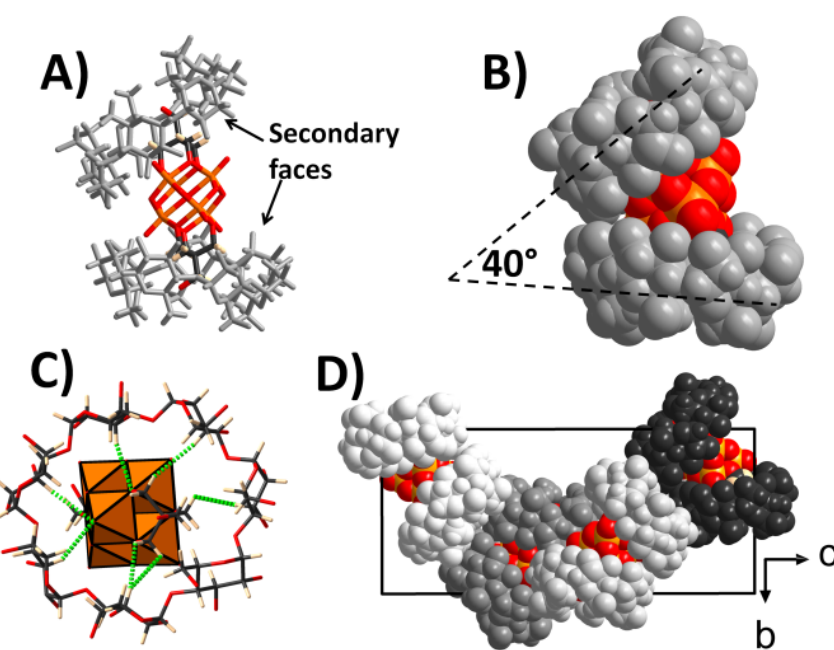

Figure 3. Wire/stick $(A)$ and space-filling $(B)$ representations of "Pac-man"type 1:2 inclusion complex $\left\{\left[\mathrm{V}_{6} \mathrm{O}_{13}\left(\left(\mathrm{OCH}_{2}\right)_{3} \mathrm{C}-\mathrm{CH}_{2} \mathrm{OH}\right)_{2}\right] 2 \beta-\mathrm{CD}\right\}^{2-}$, showing the partial embedment of the hybrid Lindqvist type anion by two $\beta$-CDs. C) Illustration showing the short contacts between the inner hydrogen atoms $(\mathrm{H} 3)$ of the $\beta-C D$ and the POV. D) View of the unit cell along the a axis highlighting the packing of the "Pac-man" complexes. Each distinct "Pacman" is represented with a different color.

$\left\{\mathbf{V}_{\mathbf{6}}\left(\mathrm{NO}_{2}\right)_{2}\right\} @ \beta-\mathbf{C D}$. The hybrid organic-inorganic solid $\mathrm{Na}_{2}\left[\mathrm{~V}_{6} \mathrm{O}_{13}\left(\left(\mathrm{OCH}_{2}\right)_{3} \mathrm{C}-\mathrm{NO}_{2}\right)_{2}\right] @\left[\left(\mathrm{C}_{6} \mathrm{H}_{10} \mathrm{O}_{5}\right)_{7}\right] \cdot 12 \mathrm{H}_{2} \mathrm{O}$ crystallizes in the space group $P_{1}$ and the asymmetric unit cell contains two polyanions and two $\beta$-CDs. Similarly to $\left\{\mathbf{V}_{6}\left(\mathbf{N O}_{2}\right)_{2}\right\} @ \alpha-C D$, the compound $\left\{\mathbf{V}_{6}\left(\mathbf{N O}_{2}\right)_{2}\right\} @ \beta-C D$ exhibits infinites supramolecular 1D chains in which the tori host bridges two POV units $\left[\mathrm{V}_{6} \mathrm{O}_{13}\left(\left(\mathrm{OCH}_{2}\right)_{3} \mathrm{C}-\mathrm{NO}_{2}\right)_{2}\right]^{2-}$ (Figure 2D-F). Most of the supramolecular interactions between the POV and the $\beta-C D$ occur through the secondary faces (Figure 2D). All hydrogen atoms $\mathrm{H} 3$ of the $\mathrm{CD}$ form short contacts with the POV through the methylene groups $\left(\mathrm{d}_{\mathrm{H} \cdots \mathrm{H}}=2.4-2.6 \AA\right)$ or through the oxygen atoms

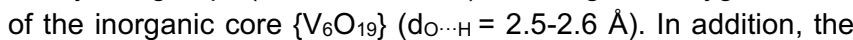
nitro group interacts also with the interior of the $\mathrm{CD}$ through $\mathrm{H} 5$ $\left(d_{0} \ldots .+2.4-2.5 \AA\right)$. The interactions between the POV and the primary face of $\beta-C D$ are weak involving only three supramolecular short contacts (Figure 2E). Contrary to $\left\{\mathbf{V}_{6}\left(\mathrm{NO}_{2}\right)_{2}\right\} @ \mathbf{\alpha}-\mathbf{C D}$, the axis defined by the two nitro groups of the $\mathrm{POV}$ are not perpendicular to the plane defined by the organic macrocycles, leading thus to some distortions of the chain $\left\{\left[\mathrm{V}_{6} \mathrm{O}_{13}\left(\left(\mathrm{OCH}_{2}\right)_{3} \mathrm{C}-\mathrm{NO}_{2}\right)_{2}\right] @ \beta-\mathrm{CD}\right\}_{\mathrm{n}}^{2 n-}$ (Figure 2F), in which the shortest distance between two nitro groups of adjacent POVs is about 3.3 $\AA$. The structural 3D cohesion is ensured by sodium cations intercalated between the chains and by short contacts between the oxygen atoms from the POVs and hydrogen atoms located at the exterior of the organic macrocycles. It is worth to note that the cavity of $\beta-C D$ allows a partial inclusion of the inorganic part $\left\{\mathrm{V}_{6} \mathrm{O}_{19}\right\}$ and not only the organic group as shown in the space-filling representation (Figure 2F). Such observations may partly explain the dramatic difference in the affinity of $\left[\mathrm{V}_{6} \mathrm{O}_{13}\left(\left(\mathrm{OCH}_{2}\right)_{3} \mathrm{C}-\mathrm{NO}_{2}\right)_{2}\right]^{2-}$ towards $\alpha-\mathrm{CD}$ and $\beta-\mathrm{CD}$, that is mainly due to the desolvation effect of POV (see solution studies).

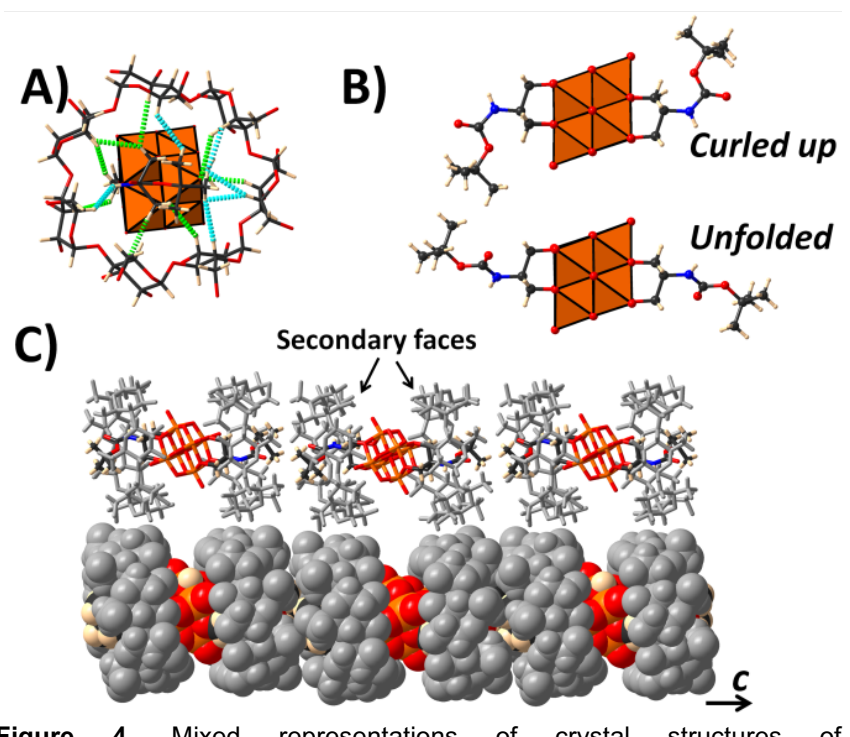

Figure 4. Mixed representations of crystal structures of $\left\{\mathbf{V}_{6}(\mathbf{N H}(B O C))_{2}\right\} @ 2 \beta-C D$. A) Illustration showing the supramolecular interaction between the inner hydrogen atoms of the $\beta-C D$ and the POV. Short contacts involving $\mathrm{H} 3$ are represented in dashed green line and those with $\mathrm{H} 5$ are in dashed cyan line. B) View of the curled up and unfolded arrangements of the hybrid POV observed in the structures of $\left\{\mathbf{V}_{6}\left(\mathbf{N H}(\mathrm{BOC})_{2}\right\} @ 2 \boldsymbol{2}-\mathbf{C D}\right.$ and those of the TBA salt, respectively. C) View of the $1 \mathrm{D}$ chain built from $1: 2$ inclusion complexes $\left\{\left[\mathrm{V}_{6} \mathrm{O}_{13}\left(\left(\mathrm{OCH}_{2}\right)_{3} \mathrm{C}\right.\right.\right.$ $\left.\left.\mathrm{NH}(\mathrm{BOC}))_{2}\right] @ 2 \beta-\mathrm{CD}\right\}^{2-}$

$\left\{\mathbf{V}_{6}\left(\mathrm{CH}_{2} \mathrm{OH}\right)_{2}\right\} @ 2 \beta-C D$. Self-assembly of $\left[\mathrm{V}_{6} \mathrm{O}_{13}\left(\left(\mathrm{OCH}_{2}\right)_{3} \mathrm{C}-\right.\right.$ $\left.\left.\mathrm{CH}_{2} \mathrm{OH}\right)_{2}\right]^{2-}$ and $\beta-\mathrm{CD}$ leads to crystal formula $\mathrm{Na}_{2}\left[\mathrm{~V}_{6} \mathrm{O}_{13}\left(\left(\mathrm{OCH}_{2}\right)_{3} \mathrm{C}-\mathrm{CH}_{2} \mathrm{OH}\right)_{2}\right] @ 2\left[\left(\mathrm{C}_{6} \mathrm{H}_{10} \mathrm{O}_{5}\right)_{7}\right] \cdot 23 \mathrm{H}_{2} \mathrm{O}$ wherein structure analysis is consistent with the non-centrosymmetric space group $P 2{ }_{1} 2{ }_{1} 2_{1}$. The asymmetric unit cell contains one crystallographically independent POV and two $\beta$-CDs. These three molecular components form together a "Pac-man"-type 1:2 host-guest complex in which the two macrocyclic hosts interact with the POV unit through their secondary face. The angle between the $C D$ planes is about $40^{\circ}$ (Figures $3 A$ and $3 B$ ). Such arrangement is quite unusual compared to those usually observed where CDs adopt a parallel face-to-face organization within 1:2 host-guest complexes. ${ }^{[14,21,24,26]}$ Geometrical parameters of the encapsulated pentaerythritol-derivatized hexavanadate anions range within those previously observed. ${ }^{[43]}$ Various weak supramolecular interactions, including short contacts, contribute to the stabilization of the host-guest motif $\left\{\left[\mathrm{V}_{6} \mathrm{O}_{13}\left(\left(\mathrm{OCH}_{2}\right)_{3} \mathrm{C}-\mathrm{CH}_{2} \mathrm{OH}\right)_{2}\right] @ 2 \beta-\mathrm{CD}\right\}^{2-}$. Two hydrogen bonds are observed between bridging oxygen atoms of the hexavanadate entities and the hydroxo groups of the secondary face of $\beta-C D$ $\left(\right.$ do $\left.\cdots o_{0}=2.8-3.0 \AA\right)$. Short contacts are observed between the terminal oxo groups of the POV unit and the inner protons $\mathrm{H} 3$ $\left(\mathrm{d}_{\mathrm{H} \cdots \mathrm{O}}=2.3-2.6 \AA\right.$; see Figure $\left.3 \mathrm{C}\right)$. The organic parts of the hybrid POV also interact through the inner protons $(\mathrm{H} 3$ and $\mathrm{H} 5)$ of $\mathrm{CD}$

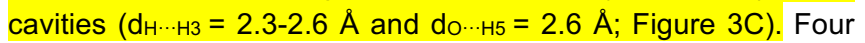
"Pac-man" units which are closely imbricated together are observed per unit cell. Each "Pac-man"-type 1:2 inclusion complex exhibits exposed inorganic surface which interacts through short contacts and hydrogen bonds with adjacent hostguest complexes (Figure 3D). The three dimensional cohesion is ensured by weak interactions between the cyclodextrins of 
distinct inclusion complexes. Two sodium cations located in the vicinity of the hydroxyl groups lying to the secondary face of $\beta-C D$ participate to the 3D cohesion of the supramolecular system. $\left\{\mathbf{V}_{6}(\mathbf{N H}(\mathrm{BOC}))_{2}\right\} @ 2 \boldsymbol{\beta}-\mathbf{C D}$. This compound, $\mathrm{Na}_{2}\left[\mathrm{~V}_{6} \mathrm{O}_{13}\left(\left(\mathrm{OCH}_{2}\right)_{3} \mathrm{C}-\right.\right.$ $\left.\mathrm{NH}\left(\mathrm{CO}_{2} \mathrm{C}\left(\mathrm{CH}_{3}\right)_{4}\right)_{2}\right] @ 2\left[\left(\mathrm{C}_{6} \mathrm{H}_{10} \mathrm{O}_{5}\right)_{7}\right] \cdot 2 \mathrm{H}_{2} \mathrm{O}$, crystallizes in a noncentrosymmetric space group $P 22_{1}$. The asymmetric unit contains four $\beta-\mathrm{CDs}$ and two $\left[\mathrm{V}_{6} \mathrm{O}_{13}\left(\left(\mathrm{OCH}_{2}\right)_{3} \mathrm{C}-\mathrm{NH}(\mathrm{BOC})\right)_{2}\right]^{2-}$ anions, forming two 1:2 inclusion complexes in which the hybrid inorganicorganic guest is embedded into two $\beta$-CDs facing their wider rim (Figure 4A). Within this inclusion complex the two CDs are separated by large distances of about $6 \AA$. This organization is unusual and results from a direct consequence of the stronger affinity of $\beta-C D$ towards the organic part. Numerous short contacts are observed between the BOC function and the inner protons of the $\beta-C D$. Interestingly, it should be noted that the structural flexibility of the guest allows a better host-guest shape/size matching. In this compound, the $\left[\mathrm{V}_{6} \mathrm{O}_{13}\left(\left(\mathrm{OCH}_{2}\right)_{3} \mathrm{C}\right.\right.$ $\left.\mathrm{NH}(\mathrm{BOC}))_{2}\right]^{2-}$ unit is curled up, whereas in the crystal structure of TBA precursor the POV adopts an unfolded conformation (Figure $4 \mathrm{~B}) \cdot{ }^{[44]}$ This adaptable behavior of $\left[\mathrm{V}_{6} \mathrm{O}_{13}\left(\left(\mathrm{OCH}_{2}\right)_{3} \mathrm{C}-\mathrm{NH}(\mathrm{BOC})\right)_{2}\right]^{2-}$ promotes the optimization of the supramolecular host-guest interactions which appear herein clearly driven by the organic function of the hybrid POM. The inclusion complexes $\left\{\left[\mathrm{V}_{6} \mathrm{O}_{13}\left(\left(\mathrm{OCH}_{2}\right)_{3} \mathrm{C}-\mathrm{NH}(\mathrm{BOC})\right)_{2}\right] @ 2 \beta-\mathrm{CD}\right\}^{2-}$ are stacked together to form a bamboo-like chain along the $c$ axis (Figure $4 \mathrm{C}$ ). Single crystal X-ray diffraction revealed the presence of sodium cations located in the vicinity of the hydroxyl groups of the $\beta-C D$, ensuring the electric balance.
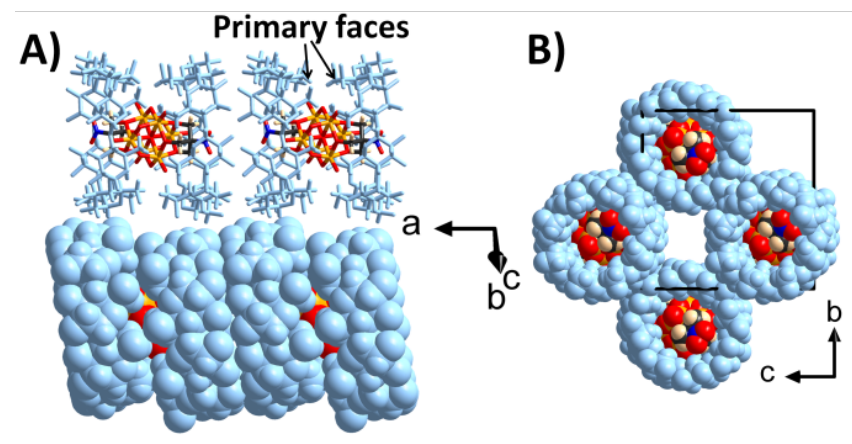

C)
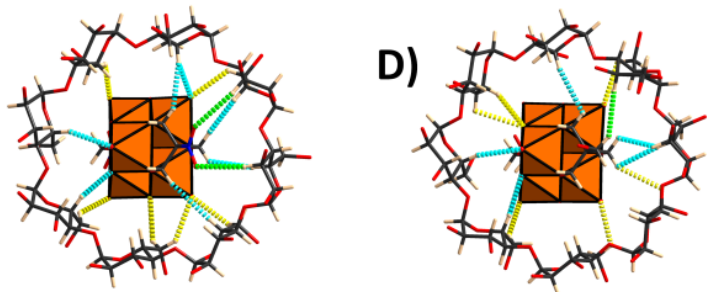

Figure 5. A) Space-filling and wire/stick representations of 1:2 inclusion complex $\left\{\left[\mathrm{V}_{6} \mathrm{O}_{13}\left(\left(\mathrm{OCH}_{2}\right)_{3} \mathrm{C}-\mathrm{NO}_{2}\right)_{2}\right] @ 2 \gamma-\mathrm{CD}\right\}^{2-}$, showing the embedment of the $\mathrm{V}_{6}$ core into two $\mathrm{Y}$-CDs that expose their primary face to the guest. $\mathrm{B}$ ) View of the bamboo-like arrangement in which the 1D cohesion is ensured by a set of hydrogen bonds between the secondary face of $\gamma-C D s . C$ ) and D) Illustrations showing the short contacts between the inner hydrogen atoms $(\mathrm{H} 3, \mathrm{H} 5, \mathrm{H} 6)$ of the $\mathrm{y}-\mathrm{CD}$ and $\left[\mathrm{V}_{6} \mathrm{O}_{13}\left(\left(\mathrm{OCH}_{2}\right)_{3} \mathrm{C}-\mathrm{NO}_{2}\right)_{2}\right]^{2-}(\mathrm{C})$ and $\left[\mathrm{V}_{6} \mathrm{O}_{13}\left(\left(\mathrm{OCH}_{2}\right)_{3} \mathrm{C}-\mathrm{CH}_{2} \mathrm{OH}\right)_{2}\right]^{2-}(\mathrm{D})$.

$\left\{\mathbf{V}_{6}\left(\mathrm{NO}_{2}\right)_{2}\right\} @ 2 \mathbf{y}-\mathbf{C D}$. This compound $\mathrm{Na}_{2}\left[\mathrm{~V}_{6} \mathrm{O}_{13}\left(\left(\mathrm{OCH}_{2}\right)_{3} \mathrm{C}\right.\right.$ $\left.\left.\mathrm{NO}_{2}\right)_{2}\right] @ 2\left[\left(\mathrm{C}_{6} \mathrm{H}_{10} \mathrm{O}_{5}\right)_{8}\right] \cdot 21 \mathrm{H}_{2} \mathrm{O}$ crystallizes in a non-centrosymmetric space group $P 2{ }_{1}$, and its asymmetric unit contains two $\mathrm{Y}$-CDs and one POV, forming a 1:2 host-guest complex (Figure
$5 A$ ). This $1: 2$ arrangement involving the hybrid $V_{6}$ Lindqvist anion differs significantly from those observed for the purely inorganic analogues $\left[\mathrm{M}_{6} \mathrm{O}_{19}\right]^{2-}$ with $\mathrm{M}=\mathrm{Mo}$ or $\mathrm{W}$ which form 1:1 host-guest complex featured by a deeply embedded POM unit into one $\gamma-C D$ torus. ${ }^{[15]}$ Attempts to crystallize the 1:1 host-guest complex with the hybrid hexavanadate as guest systematically failed. In the supramolecular adduct $\left\{\mathbf{V}_{6}\left(\mathbf{N O}_{2}\right)_{2}\right\} @ 2 y-C D$, cyclodextrin host interacts with the POV unit through the primary faces as frequently reported for the inclusion complexes built from $\mathrm{y}$-CDs and Keggin and Dawson type polyoxometalates. ${ }^{[14,17,19,28]}$ The inclusion complexes are stacked together along the $a$ axis forming a bamboo-like arrangement (Figure 5B) within a network directed by hydrogen bonds ( $\mathrm{d}_{0} \ldots \mathrm{O}=2.7-3.1 \AA$ ) that interconnect secondary rims of neighbored 1:2 host-guest motifs. The space filling representation shows the full embedment of the POV into the cavity of the $\mathrm{Y}$-CDs, while the organic tails point out the center of CDs cavity (Figure 5A). Thus, the main host-guest interactions are observed between the oxygen atoms of the $\left\{\mathrm{V}_{6} \mathrm{O}_{19}\right\}$ core and protons $\mathrm{H}_{6}$ and $\mathrm{H}_{5}$ of the $\mathrm{CDs}$ ( $\mathrm{d}_{\mathrm{O} \cdots \mathrm{H}}=2.5-2.7 \AA$, Figure $5 \mathrm{C}$ ). In addition, the organic part of the POV unit interacts with inner protons of the torus host through numerous short contacts. The structure analysis did not allow the localization of the counter cations which remain probably disordered in the void tunnel lined by four adjacent 1D bamboos (Figure 5B).

$\left\{\mathbf{V}_{6}\left(\mathrm{CH}_{2} \mathrm{OH}\right)_{2}\right\} @ 2 \mathbf{y}-\mathbf{C D}$. This compound $\mathrm{Na}_{2}\left[\mathrm{~V}_{6} \mathrm{O}_{13}\left(\left(\mathrm{OCH}_{2}\right)_{3} \mathrm{C}\right.\right.$ $\left.\left.\mathrm{CH}_{2} \mathrm{OH}\right)_{2}\right] @ 2\left[\left(\mathrm{C}_{6} \mathrm{H}_{10} \mathrm{O}_{5}\right)_{8}\right] \cdot 24 \mathrm{H}_{2} \mathrm{O}$ is isostructural with $\left\{\mathbf{V}_{6}\left(\mathrm{NO}_{2}\right)_{2}\right\} @ 2 y-C D$ (see tables S5-S6) and consequently exhibits the same packing of the 1:2 host-guest complexes. Within the inclusion complex, the pentaerythritol functionalized POV interacts with $\mathrm{Y}-\mathrm{CD}$ through numerous short contacts similar to those observed with the nitro derivative (see Figures $5 \mathrm{C}$ and 5D). Importantly, $\quad\left[\mathrm{V}_{6} \mathrm{O}_{13}\left(\left(\mathrm{OCH}_{2}\right)_{3} \mathrm{C}-\mathrm{NO}_{2}\right)_{2}\right]^{2-}$ and $\left[\mathrm{V}_{6} \mathrm{O}_{13}\left(\left(\mathrm{OCH}_{2}\right)_{3} \mathrm{C}-\right.\right.$ $\left.\left.\mathrm{CH}_{2} \mathrm{OH}\right)_{2}\right]^{2-}$ adopt the same host-guest conformation based upon similar host-guest interactions in the solid-state. Nevertheless, the solution studies reveal two distinct supramolecular behaviors in water, suggesting that the main driving force of the association is related to the solvent effects that overcome the sum of very weak "classical" attractive forces, such as dispersion forces, ion-dipole or hydrogen bonding.

\section{Solution studies}

The structural analysis of the six host-guest arrangements does not evidence any significant attractive interactions between the various hybrid hexavanadates and the CDs. Therefore, the investigations about the origin of the driving forces responsible of the self-assembly processes have been carried out in solution. To assess strength and mode of supramolecular interaction between native CDs and Lindqvist hexavanadates functionalized with tris(hydroxymethyl)methane-derived ligands, titration experiments were conducted using ITC, ${ }^{1} \mathrm{H}$ NMR spectroscopy and cyclic voltammetry. In addition, DOSY NMR studies were carried out to give further insights about existence of the supramolecular interaction in solution and ROESY NMR have been employed to probe the host-guest contact through space occurring in solution. 
Table 1. Binding modes and binding constants $\left(\mathrm{M}^{-1}\right)$ of native CD with the different POVs measured by NMR, electrochemistry, and ITC. Thermodynamic

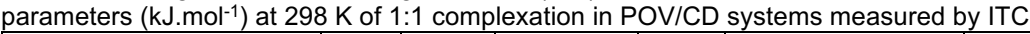

\begin{tabular}{|c|c|c|c|c|c|c|c|c|}
\hline++ & \begin{tabular}{|l|}
$\Delta_{\mathrm{r}} \mathrm{H}^{*}$ \\
(ITC) \\
\end{tabular} & $\begin{array}{l}\mathrm{T} \Delta \Delta_{\mathrm{r}} \mathrm{S}^{*} \\
\text { (ITC) }\end{array}$ & $\begin{array}{l}\Delta \mathbf{r}^{*} \\
(\text { ITC) }\end{array}$ & $\begin{array}{l}K_{1: 1}^{o x} \\
\text { (ITC) }\end{array}$ & $\begin{array}{c}\text { Binding Mode } \\
\text { (NMR) }\end{array}$ & $\begin{array}{c}K_{1: 1}^{o x} \\
\text { (NMR) }\end{array}$ & $\begin{array}{c}K_{1: 1}^{o x} \\
\text { (Electrochemistry) }\end{array}$ & $\begin{array}{c}K_{1: 1}^{r e d} \\
\text { (Electrochemistry) }\end{array}$ \\
\hline $\mathrm{V}_{6}-\left(\mathrm{NO}_{2}\right)_{2} / \mathbf{a}-\mathrm{CD}$ & -1.8 & 14.6 & -16.3 & 733 & Primary face & $300 \pm 40$ & 300 & 400 \\
\hline $\mathrm{V}_{6}-\left(\mathrm{NO}_{2}\right)_{2} / \boldsymbol{\beta}-\mathrm{CD}$ & -45.6 & -29.9 & -15.7 & 574 & Secondary face & $470 \pm 50$ & 500 & 80 \\
\hline $\mathrm{V}_{6}-\left(\mathrm{NO}_{2}\right)_{2} / \mathbf{Y}-\mathrm{CD}$ & -24.4 & -6.0 & -18.3 & 1644 & Primary face & $1360 \pm 60$ & 2000 & 0 \\
\hline $\mathrm{V}_{6}-\left(\mathrm{CH}_{2} \mathrm{CH}_{3}\right)_{2} / \mathbf{\alpha}-\mathbf{C D}$ & -3.9 & 10.9 & -14.7 & 381 & Secondary face & $230 \pm 20$ & 60 & 500 \\
\hline $\mathrm{V}_{6}-\left(\mathrm{CH}_{2} \mathrm{CH}_{3}\right)_{2} / \boldsymbol{\beta}-\mathrm{CD}$ & -32.5 & -18.4 & -14.5 & 344 & Secondary face & $700 \pm 100$ & 450 & 150 \\
\hline $\mathrm{V}_{6}-\left(\mathrm{CH}_{2} \mathrm{OH}\right)_{2} / \boldsymbol{\alpha}-\mathrm{CD}$ & - & - & - & - & - & - & - & - \\
\hline $\mathrm{V}_{6}-\left(\mathrm{CH}_{2} \mathrm{OH}\right)_{2} / \boldsymbol{\beta}-\mathrm{CD}$ & -19.2 & -5.0 & -14.1 & 301 & Secondary face & $290 \pm 30$ & 300 & 70 \\
\hline $\mathrm{V}_{6}-\left(\mathrm{CH}_{2} \mathrm{OH}\right)_{2} / \mathbf{Y}-\mathbf{C D}$ & -4.2 & 12.2 & -16.4 & 765 & Primary face & $90 \pm 20$ & 100 & 10 \\
\hline $\mathrm{V}_{6}-(\mathrm{NH}(\mathrm{BOC}))_{2} / \boldsymbol{\alpha}-\mathrm{CD}$ & -33.0 & -20.6 & -12.4 & 151 & Primary face & $358 \pm 9$ & 250 & 250 \\
\hline $\mathrm{V}_{6}-(\mathrm{NH}(\mathrm{BOC}))_{2} / \boldsymbol{\beta}-\mathrm{CD}$ & -20.6 & -4.2 & -17.9 & 1395 & Secondary face & $1200 \pm 100$ & 1200 & 150 \\
\hline $\mathrm{V}_{6}-(\mathrm{NH}(\mathrm{BOC}))_{2} / \mathbf{Y}-\mathrm{CD}$ & -12.4 & 3.8 & -16.2 & 696 & Primary face & $1000 \pm 100$ & 1000 & 0 \\
\hline
\end{tabular}

a The binding mode is deduced from the deshielding effect on the proton H6: primary face, when observed; secondary face when not observed.

Isothermal Titration Calorimetry. ITC experiments were carried out to provide binding constants $\mathrm{K}_{1: 1}$ and detailed thermodynamic data associated to the molecular recognition processes. ITC thermograms and isotherms are shown in Supporting Information section (see Figures S35-S38). Thermodynamic parameters at $298 \mathrm{~K}, \Delta \mathrm{r} H^{*}$ and $\Delta \mathrm{r} S^{*}$ are given in Table 1.

For POV/CD systems, the variation of enthalpy contribution is systematically counterbalanced by entropy according to enthalpy-entropy compensation usually observed as a quasilinear correlation (see Figure S39). Actually, analysis of the thermodynamic parameters gives no clear trend. Nevertheless the most stable adducts are those involving the nitro derivative showing $\Delta \mathrm{G}_{298}$ from ca. -16 to $-18 \mathrm{~kJ} / \mathrm{mol}$, that would indicate that the organic tails contributes in some extent to the host-guest stability. We also notice that adducts involving $\alpha-C D$ are among the least stable $\left(\mathrm{K}_{1: 1}<400 \mathrm{M}^{-1}\right.$ except for $\left.\mathrm{V}_{6}-\left(\mathrm{NO}_{2}\right)_{2}\right)$, probably due to the host-guest size matching effect which is less effective with the smallest cyclic host. Nonetheless, other considerations could also account in the recognition process. For instance, the hydrophobic character of the organic part, in particular $\left(\mathrm{OCH}_{2}\right)_{3} \mathrm{C}$ $\left(\mathrm{CH}_{2} \mathrm{CH}_{3}\right)$ or $\left(\mathrm{OCH}_{2}\right)_{3} \mathrm{C}-(\mathrm{NH}(\mathrm{BOC}))$ may also contribute in strengthening the host-guest association. In most of cases inclusion complexations are enthalpically driven processes However entropy contribution is clearly prominent with the systems $\mathrm{V}_{6}-\left(\mathrm{NO}_{2}\right)_{2} / \alpha-\mathrm{CD}\left(\mathrm{T} \Delta_{\mathrm{r}} \mathrm{S}=14.6 \mathrm{~kJ} \cdot \mathrm{mol}^{-1}\right)$ and $\mathrm{V}_{6}$ $\left.\left(\mathrm{CH}_{2} \mathrm{CH}_{3}\right)_{2} / \alpha-\mathrm{CD}\left(\mathrm{T} \Delta_{\mathrm{r}} \mathrm{S}=10.9 \mathrm{~kJ} \mathrm{~mol}^{-1}\right)\right)$. Entropically monitored processes are also observed with $\mathrm{V}_{6}-\left(\mathrm{CH}_{2} \mathrm{CH}_{3}\right)_{2} / \gamma-\mathrm{CD}(\mathrm{T} \Delta \mathrm{r} \mathrm{S}=$ $\left.12.2 \mathrm{~kJ} \mathrm{~mol}^{-1}\right)$ and $\mathrm{V}_{6}-(\mathrm{NH}(\mathrm{BOC}))_{2} / \gamma-\mathrm{CD}\left(\mathrm{T} \Delta_{\mathrm{r}} \mathrm{S}=3.8 \mathrm{~kJ} \cdot \mathrm{mol}^{-1}\right)$ that usually features hydrophobic driven associations. ${ }^{[21,22,45]}$ In summary, the lack of clear trend may indicate complex complexation pathways arising from the organic patches that involve hydrophobic and chaotropic effect supported by hostguest size matching.

${ }^{1} \mathrm{H}$ NMR spectroscopy. The interactions between the vanadium containing Lindqvist derivatives and $\mathrm{CDs}$ have been also investigated by ${ }^{1} \mathrm{H}$ NMR spectroscopy, using titration experiments. ROESY and DOSY methods were also employed for some selected samples to gain further insights about solution behavior. Systematic titration experiments have been carried out for all combinations between the four hybrid POV compounds and the three types of $C D$ (see Supporting Information for full data) varying progressively the amount of POV in a solution of $2 \mathrm{mM}$ fixed CD concentration. Figures 6-7 show ${ }^{1} \mathrm{H}$ NMR spectra of $\alpha$ and $\beta-C D$ before and after addition of POV (6-9 equivalents), and the corresponding variation of the $\mathrm{H} 5 / \mathrm{H} 6$ chemical shifts as a function of POV/CD molar ratio.

${ }^{1} \mathrm{H}$ NMR spectra of $\alpha-C D$ (Figure 6 ) show only small changes upon addition of $\mathrm{Na}_{2}\left[\mathrm{~V}_{6} \mathrm{O}_{13}\left(\left(\mathrm{OCH}_{2}\right)_{3} \mathrm{C}-\mathrm{R}\right)_{2}\right]$ indicating that supramolecular interactions remain weak. No significant variation of the spectra can be observed with the $-\mathrm{CH}_{2} \mathrm{OH}$ derivative, and only very tiny shifts are detected with the nitro derivative $(\mathrm{R}=$ $\mathrm{NO}_{2}$ ), suggesting almost no interaction occurring in solution between these hybrid POVs and $\alpha-\mathrm{CD}$. Using $-\mathrm{NH}(\mathrm{BOC})$ and $\mathrm{CH}_{2} \mathrm{CH}_{3}$ derivatives, we however observe significant shifts of $\mathrm{H} 5$ signal indicating these POVs do interact with $\alpha-C D$ in aqueous solution. It is worthy to note that the shift direction is different. While $\mathrm{H} 5$ signal moves to low field with $-\mathrm{NH}(\mathrm{BOC})$ derivative, it shifts to high field in case of $\left[\mathrm{V}_{6} \mathrm{O}_{13}\left(\left(\mathrm{OCH}_{2}\right)_{3} \mathrm{C}-\mathrm{CH}_{2} \mathrm{CH}_{3}\right)_{2}\right]^{2-}$ that could suggest different binding modes. As $\mathrm{H} 6$ signal is also strongly affected in the case of $-\mathrm{NH}(\mathrm{BOC}) \mathrm{POV}$ derivatives, the shielding of $\mathrm{H} 5$ signal may indicate an interaction of the $\mathrm{CD}$ through its primary face. We can thus conclude from the NMR results that $\alpha-C D$ interacts in solution with $\mathrm{V}_{6}\left(\left(\mathrm{OCH}_{2}\right)_{3} \mathrm{C}\right.$ $\mathrm{NH}(\mathrm{BOC}))_{2}{ }^{2-}$ mostly through its primary face and through secondary face with $\mathrm{V}_{6}\left(\left(\mathrm{OCH}_{2}\right)_{3} \mathrm{C}-\mathrm{CH}_{2} \mathrm{CH}_{3}\right)_{2}{ }^{2-}$.

In the case of $\beta-C D$ (Figure 7), all hybrid POVs interact strongly as shown by the $\mathrm{H} 5$ signal that undergoes the significant shielding. This probably means that all $V_{6}$ derivatives form supramolecular adducts with $\beta-C D$. According to the NMR analysis based on the weak effect for the $\mathrm{H} 6$ signal, these interactions should involve mostly secondary faces. In the presence of the largest macrocycle $\mathrm{Y}-\mathrm{CD}$ (Figure 8), the situation is different and rather consistent with interactions which take place on the primary face $(\mathrm{H} 5$ resonance moves together with $\mathrm{H} 6$ resonance towards low fields). Interestingly, the ${ }^{1} \mathrm{H}$ NMR investigation reveals the strength of the supramolecular association between $\mathrm{Y}-\mathrm{CD}$ and the POVs $\left[\mathrm{V}_{6} \mathrm{O}_{13}\left(\left(\mathrm{OCH}_{2}\right)_{3} \mathrm{C}-\mathrm{R}\right)_{2}\right]^{2-}$ with $\mathrm{R}=-\mathrm{NO}_{2}$ and $-\mathrm{CH}_{2} \mathrm{OH}$ differs strongly $\left(\mathrm{K}_{1: 1}\right.$ values of 1360 and 90 for $\mathrm{R}=-\mathrm{NO}_{2}$ and $-\mathrm{CH}_{2} \mathrm{OH}$, respectively), while similar weak "classical" attractive forces was observed on crystallized host-guest complexes (see Figure 5C and 5D). This observation suggests the hydration properties of the hybrid organic-inorganic 
guests should be considered to understand their supramolecular behavior in solution.

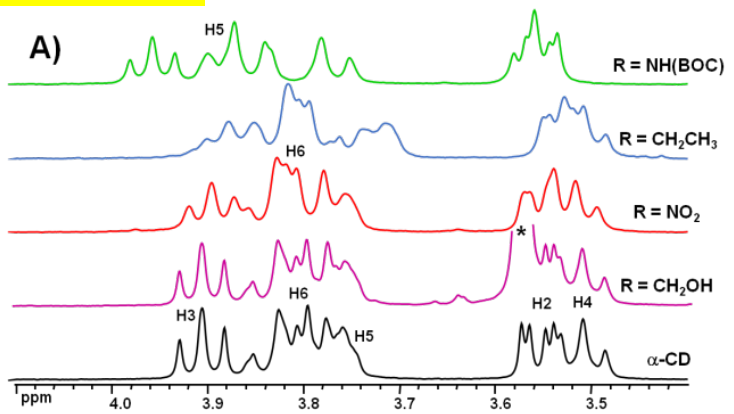

B)

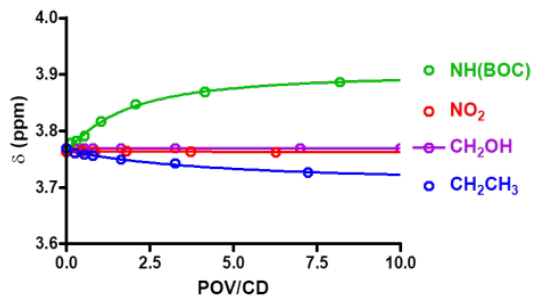

Figure 6. A) ${ }^{1} \mathrm{H}$ NMR spectra of $2 \mathrm{mM}$ a-CD in aqueous solution in the 3.4$4.1 \mathrm{ppm}$ range before and after introducing 6 equivalents of $\mathrm{Na}_{2}\left[\mathrm{~V}_{6} \mathrm{O}_{13}\left(\left(\mathrm{OCH}_{2}\right)_{3} \mathrm{C}-\mathrm{R}\right)_{2}\right]$. Asterisk in the case of $\mathrm{R}=\mathrm{CH}_{2} \mathrm{OH}$ indicates the signal of the POV overlapping with signal $\mathrm{H} 2$ of the $\alpha-C D$. B) Plots of the chemical shifts of the $\mathrm{H} 5$ as a function of POV/CD molar ratio.

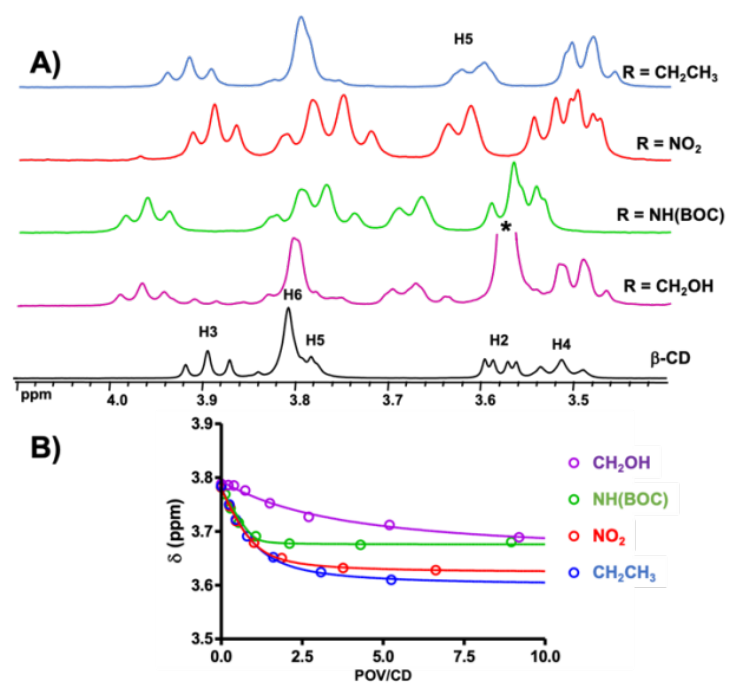

Figure 7. A) ${ }^{1} \mathrm{H}$ NMR spectra of $2 \mathrm{mM} \beta-\mathrm{CD}$ aqueous solution in the 3.4$4.1 \mathrm{ppm}$ range without and in the presence of 9 equivalents of $\mathrm{Na}_{2}\left[\mathrm{~V}_{6} \mathrm{O}_{13}\left(\left(\mathrm{OCH}_{2}\right)_{3} \mathrm{C}-\mathrm{R}\right)_{2}\right]$. Asterisk in the case of $\mathrm{R}=\mathrm{CH}_{2} \mathrm{OH}$ indicates the signal of the POV. B) Plots of the H5 chemical shifts of the $\beta-C D$ as a function of POV/CD molar ratio.

DOSY NMR has been shown to be powerful in tracking supramolecular aggregates while conventional NMR could fail to demonstrate contact interactions in solution. The observed diffusion coefficient $(D)$ represents a weighted average value of the different interacting species in equilibrium. Table 2 summarizes the overall results obtained with equimolar solutions $(2 \mathrm{mM})$ of mixed and separated CD and POV species. As a general trend, we observe a systematic decrease of $D$ values of both $C D$ and POV in the binary systems as an indication of mutual interaction slowing down their diffusion rate in solution. The relative decrease of $C D$ diffusion coefficient is comparatively smaller than those of the POV because of the difference in size between the host and the guest. The diffusion of the smaller POV species appears then more sensitive than that of the larger CD molecule, and then more appropriate to be used to evidence interaction in solution. The extent of the variation depends on the nature of the host guest system. While tiny changes in $D(3-6 \%)$ are observed in $\alpha-C D$ systems, $\beta-C D$ containing solutions exhibited the largest variation of $D(12-30 \%)$. This is consistent with previous 1D NMR analysis or ITC data evidencing weak interaction of $\alpha-C D$ with hybrid POVs and highest binding constants with $\beta-C D$ (see Table 1). On the other hand, POV with $\mathrm{R}=\mathrm{CH}_{2} \mathrm{OH}$ showed the lowest affinity toward CDs $(D$ decreased by only $3-12 \%$ ), while the strongest interactions were observed with the nitro derivative (up to $-33 \%$ of $D$; see figure $\mathrm{S} 19$ ).

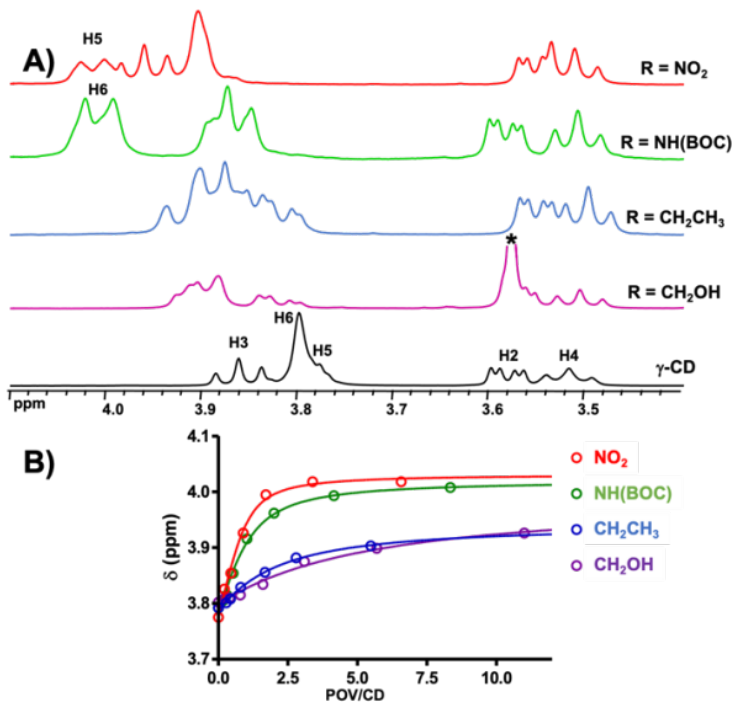

Figure 8. A) ${ }^{1} \mathrm{H}$ NMR spectra of $2 \mathrm{mM} \mathrm{y}-\mathrm{CD}$ aqueous solution in the 3.4$4.1 \mathrm{ppm}$ range without and in the presence of 8 equivalents of $\mathrm{Na}_{2}\left[\mathrm{~V}_{6} \mathrm{O}_{13}\left(\left(\mathrm{OCH}_{2}\right)_{3} \mathrm{C}-\mathrm{R}\right)_{2}\right]$. Asterisk in the case of $\mathrm{R}=\mathrm{CH}_{2} \mathrm{OH}$ indicates the signal of the POV overlapping with signal $\mathrm{H} 2$ of the $\mathrm{CD}$. B) Plots of the $\mathrm{H} 5$ chemical shifts $\gamma-\mathrm{CD}$ ( $\mathrm{H} 5$ for $\mathrm{R}=\mathrm{CH}_{2} \mathrm{OH}, \mathrm{CH}_{2} \mathrm{CH}_{3}$, and $\mathrm{NO}_{2}$, and $\mathrm{H} 6$ for $\mathrm{R}$ $=\mathrm{NH}(\mathrm{BOC})$ as a function of $\mathrm{POV} / \mathrm{CD}$ molar ratio.

Table 2: Summary of diffusion coefficient (in $\mu \mathrm{m}^{2} \cdot \mathrm{s}^{-1}$ ) $\mathrm{a}$ of $C D$ and $V_{6}-(R)_{2}$ in an $2 \mathrm{mM}$ equimolar mixture compared to corresponding separate aqueous solutions of $\mathrm{CD}$ and $\mathrm{POV}$ as measured by DOSY NMR

\begin{tabular}{|c|c|c|c|c|c|c|c|c|}
\hline & \multicolumn{2}{|c|}{$\mathrm{V}_{6}-\left(\mathrm{CH}_{2} \mathrm{OH}\right)_{2}$} & \multicolumn{2}{|c|}{$\mathrm{V}_{6}-\left(\mathrm{CH}_{2} \mathrm{CH}_{3}\right)_{2}$} & \multicolumn{2}{|c|}{$\mathrm{V}_{6}-\left(\mathrm{NO}_{2}\right)_{2}$} & \multicolumn{2}{|c|}{$\mathrm{V}_{6-}(\mathrm{NH}(\mathrm{BOC}))_{2}$} \\
\hline & $D_{C D}$ & $D_{\text {Pov }}$ & $D_{C D}$ & $D_{\text {POV }}$ & $D_{C D}$ & $D_{\text {POV }}$ & $D_{C D}$ & $D_{\text {POV }}$ \\
\hline POV & & 422 & & 410 & & 450 & & 347 \\
\hline$\alpha-C D$ & 294 & & 294 & & 294 & & 294 & \\
\hline$a-C D / P O V$ & $\begin{array}{c}295 \\
(0 \%) \\
\end{array}$ & $\begin{array}{c}408 \\
(-3 \%)\end{array}$ & $\begin{array}{c}285 \\
(-3 \%) \\
\end{array}$ & $\begin{array}{c}393 \\
(-4 \%) \\
\end{array}$ & $\begin{array}{c}295 \\
(0 \%) \\
\end{array}$ & $\begin{array}{c}436 \\
(-3 \%)\end{array}$ & \begin{tabular}{|c|}
285 \\
$(-3 \%)$ \\
\end{tabular} & \begin{tabular}{|c|}
325 \\
$(-6 \%)$ \\
\end{tabular} \\
\hline$\beta-C D$ & 276 & & 276 & & 276 & & 276 & \\
\hline$\beta-\mathrm{CD} / \mathrm{POV}$ & $\begin{array}{c}265 \\
(-4 \%) \\
\end{array}$ & $\begin{array}{c}370 \\
(-12 \%) \\
\end{array}$ & $\begin{array}{c}257 \\
(-7 \%) \\
\end{array}$ & $\begin{array}{c}325 \\
(-21 \%) \\
\end{array}$ & \begin{tabular}{|c|}
245 \\
$(-11 \%)$ \\
\end{tabular} & $\begin{array}{c}315 \\
(-30 \%) \\
\end{array}$ & \begin{tabular}{|c|}
233 \\
$(-16 \%)$ \\
\end{tabular} & $\begin{array}{c}267 \\
(-23 \%) \\
\end{array}$ \\
\hline$y-C D$ & 254 & & 254 & & 254 & & 254 & \\
\hline $\mathrm{Y}-\mathrm{CD} / \mathrm{POV}$ & $\begin{array}{c}253 \\
(0 \%) \\
\end{array}$ & $\begin{array}{c}383 \\
(-9 \%)\end{array}$ & $\begin{array}{c}244 \\
(-4 \%)\end{array}$ & $\begin{array}{c}345 \\
(-16 \%)\end{array}$ & $\begin{array}{c}241 \\
(-5 \%)\end{array}$ & $\begin{array}{c}303 \\
(-33 \%)\end{array}$ & $\begin{array}{c}235 \\
(-7 \%)\end{array}$ & $\begin{array}{c}276 \\
(-20 \%) \\
\end{array}$ \\
\hline
\end{tabular}

${ }^{a}$ Estimated errors are within 1-2\%. Values in parentheses represent the variation with respect to the corresponding solution of pure compound (CD or POV).

ROESY NMR has been employed to probe the contact through space occurring in solution between $C D$ and hybrid POV in an equimolar mixture. The spectra of $1 / 1$ solutions of $\beta-C D / N_{6}-$ $\left(\mathrm{CH}_{2} \mathrm{OH}\right)_{2}, \quad \beta-\mathrm{CD} / \mathrm{V}_{6}-\left(\mathrm{CH}_{2} \mathrm{CH}_{3}\right)_{2}, \quad \beta-\mathrm{CD} / \mathrm{V}_{6}-\left(\mathrm{NO}_{2}\right)_{2}$, and $\alpha-\mathrm{CD} / \mathrm{N}_{6}-$ $(\mathrm{NH}(\mathrm{BOC}))_{2}$ are shown in Figures S13-16 (Supporting Information) as representative systems. The strongest 
correlations were observed between the organic part of $\mathrm{V}_{6}$ $\left(\mathrm{CH}_{2} \mathrm{OH}\right)_{2}$ derivative and internal $\mathrm{H} 3$ and especially $\mathrm{H} 5$ protons of $\beta-C D$ nearly consistent with the host-guest structure observed in the solid-state (see Figures 2-3). With $\left[\mathrm{V}_{6} \mathrm{O}_{13}\left(\left(\mathrm{OCH}_{2}\right)_{3} \mathrm{C}\right.\right.$ $\left.\left.\mathrm{CH}_{2} \mathrm{CH}_{3}\right)_{2}\right]^{2-}$ anion, the terminal methyl groups interact with $\mathrm{H} 5$ and $\mathrm{H} 6$ while the $\mathrm{CH}_{2}$ groups closer to the inorganic part of the POV show an additional correlation with the $\mathrm{H} 3$ protons which confirms the deep inclusion of the hydrophobic arm inside the $\beta$ CD cavity. At last, ROESY correlations are consistent with encapsulation of the hybrid POV into the organic macrocycle through its exposed organic moieties. This is a general scheme in such hybrid POV/CD associations.

\section{Cyclic voltammetry.}

Previous electrochemical studies have revealed that redoxproperties of the Keggin type POMs could be strongly altered by $\gamma$-CD complexation. ${ }^{[19,20]}$ This observation prompted us to investigate how native $\mathrm{CDs}$ affect electrochemical properties of Lindqvist-type polyoxovanadates $\left[\mathrm{V}_{6} \mathrm{O}_{13}\left(\left(\mathrm{OCH}_{2}\right)_{3} \mathrm{C}-\mathrm{R}\right)_{2}\right]^{2-}$ which are known to undergo a quasi-reversible one-electron transfer leading to the reduced mixed valence core $\left\{\mathrm{V}^{\mathrm{IV}}{ }_{1} \mathrm{~V}_{5}{ }_{5}{ }^{[46]}\right.$

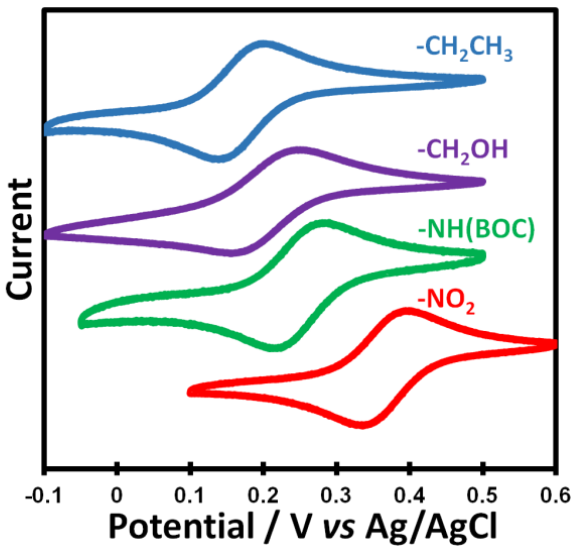

Figure 9. Cyclovoltammograms of $\left[\mathrm{V}_{6} \mathrm{O}_{13}\left(\left(\mathrm{OCH}_{2}\right)_{3} \mathrm{C}-\mathrm{R}\right)_{2}\right]^{2-}$ anions with $\mathrm{R}$ $=\mathrm{CH}_{2} \mathrm{OH} ; \mathrm{CH}_{2} \mathrm{CH}_{3}, \mathrm{NH}(\mathrm{BOC})$ and $\mathrm{NO}_{2}$ in aqueous solution $(\mathrm{pH}=6$; [POV] $=1 \mathrm{mM}$ ). Scan rate: $50 \mathrm{mV} / \mathrm{s}$; working electrode: glassy carbon; reference electrode: $\mathrm{Ag} / \mathrm{AgCl}$; counter electrode: $\mathrm{Pt}$

Surprisingly, the redox studies of the Lindqvist-type polyoxovanadates $\left[\mathrm{V}_{6} \mathrm{O}_{13}\left(\left(\mathrm{OCH}_{2}\right)_{3} \mathrm{C}-\mathrm{R}\right)_{2}\right]^{2-}$ in aqueous solution are scarce and only those of the hybrid POV with $\mathrm{R}=\mathrm{CH}_{2} \mathrm{OH}$ were reported. ${ }^{[43]}$ We measured the cyclic voltammograms of the POVs with $\mathrm{R}=\mathrm{CH}_{2} \mathrm{CH}_{3}, \mathrm{NO}_{2}, \mathrm{CH}_{2} \mathrm{OH}$ and $\mathrm{NH}(\mathrm{BOC})$ in aqueous solution $\left(\mathrm{pH}=6 ;\left[\mathrm{Na}_{2} \mathrm{SO}_{4}\right]=0.5 \mathrm{M}\right)$. Each POV exhibits a single one-electron reversible reduction process occurring within the $+0.15-+0.4 \mathrm{~V}$ range with respect to $\mathrm{Ag} / \mathrm{AgCl}$ (see Figure 9). This redox event appears almost unaffected in $\mathrm{pH}$ range from 4 to 9 that is consistent with the absence of proton-coupled electron transfer. As expected, the nature of the functional $R$ group influences the half-wave potential of the couple $\mathrm{POV}^{2-} / \mathrm{POV}^{3-}$. The $E_{1 / 2}$ is observed at $+177.5,+202,+250$, and $+370 \mathrm{mV}$ vs $\mathrm{Ag} / \mathrm{AgCl}$ for $\mathrm{R}=\mathrm{CH}_{2} \mathrm{CH}_{3}, \mathrm{CH}_{2} \mathrm{OH}, \mathrm{NH}(\mathrm{BOC})$ and $\mathrm{NO}_{2}$, respectively. The $\mathrm{E}_{1 / 2}$ for $\mathrm{R}=\mathrm{CH}_{2} \mathrm{OH}$ is in good agreement with previous report. ${ }^{[43]}$ The value of $\mathrm{E}_{1 / 2}$ appears nicely correlated to the inductive effect of functional $R$ group. Thus, the POV containing the nitro patch identified as the most electronwithdrawing group exhibits the higher $\mathrm{E}_{1 / 2}$ meaning the $\mathrm{NO}_{2}$ group favors the stabilization of reduced form. Nevertheless the influence of the functional $R$ group on $E_{1 / 2}$ appears much less pronounced in aqueous solution than that observed in organic solvents (DMF). Indeed, Zubieta and coworker ${ }^{[46]}$ observed a gap of $+500 \mathrm{mV}$ between $-\mathrm{NO}_{2}$ and $-\mathrm{CH}_{2} \mathrm{OH}$ functionalized POVs which fall down to $+168 \mathrm{mV}$ in aqueous solution.
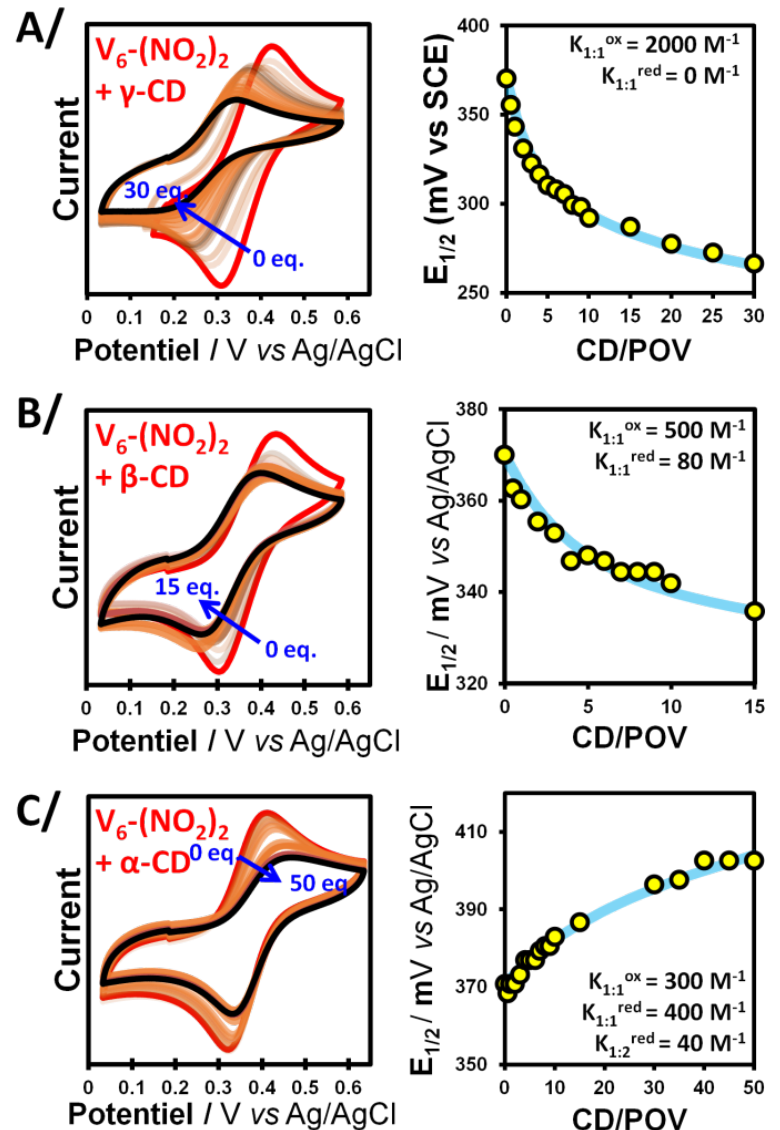

Figure 10. (left) Evolution of the $\mathrm{CVs}$ of $\mathrm{V}_{6}-\left(\mathrm{CH}_{2} \mathrm{OH}\right)_{2}(1 \mathrm{mM})$ in presence of increasing amount of $\gamma-(A), \beta-(B)$, and $\alpha-C D(C)$. Scan rate: $100 \mathrm{mV} / \mathrm{s}$; (right) Variation of half-wave potential of the couple POV $^{2-} / \mathrm{POV}^{3-}$ observed in $\mathrm{CV}$ s as a function of molar ratio CD/POV. The blue curve corresponds to the best fit of experimental measurements (yellow circles).

Importantly the presence of native cyclodextrins in aqueous solution influences the redox properties of the POVs in a magnitude similar to that observed using the covalent functionalization of POV unit. The most impressive effect is observed for the nitro functionalized POVs where the first redox wave exhibits opposite shifts of -104 and $+33 \mathrm{mV}$ in presence of $\gamma-C D$ and $\alpha-C D$, respectively (Figure 10 ). The simplicity of these reversible supramolecular associations offers an appealing route to tune the electronic properties of POVs in aqueous solution. It is worth to note the opposite shift in potential of the first wave depending upon the nature of the $\mathrm{CD}$. For instance, the interaction of $V_{6}-\left(N_{2}\right)_{2}$ with $\beta-C D$ and $Y-C D$ is featured by a gradual decreasing of the half-wave potential associated with a substantial decrease of the peak currents (Figure $10 \mathrm{~A}$ and B). This variation of the half-wave potential is consistent with an decrease of the host-guest affinity through the reduced POV $\left[\mathrm{V}_{6} \mathrm{O}_{13}\left(\left(\mathrm{OCH}_{2}\right)_{3} \mathrm{C}-\mathrm{NO}_{2}\right)_{2}\right]^{3-}$, suggesting the driving force of the supramolecular association is mostly due to the chaotropic effect. ${ }^{[19,20,25]}$ This conclusion is supported by our ITC measurement that indicates the binding of the $\left[\mathrm{V}_{6} \mathrm{O}_{13}\left(\left(\mathrm{OCH}_{2}\right)_{3} \mathrm{C}\right.\right.$ $\left.\left.\mathrm{NO}_{2}\right)_{2}\right]^{2-}$ with $\beta-C D$ and $\gamma-C D$ is an enthalpically driven process 
accompanied by significant entropic penalty (see table 1), which feature the encapsulation of chaotrope specie into $C D$ macrocycles. ${ }^{[22]}$ Furthermore, the decrease of the peak currents due to the decrease of the diffusion coefficient should result from the formation of supramolecular adducts POV/CD. The gradual decrease of the half wave potential of $\mathrm{V}_{6}-\left(\mathrm{NO}_{2}\right)_{2}$ upon the addition of 10 equiv of $C D s$ is much more pronounced with $\mathrm{y}-\mathrm{CD}(-78 \mathrm{mV})$ than with $\beta-C D(-28 \mathrm{mV})$. The electrochemical behavior of $\mathrm{V}_{6}$ $\left(\mathrm{CH}_{2} \mathrm{CH}_{3}\right)_{2}$ (Figures S27-S28), $\mathrm{V}_{6}-(\mathrm{NH}(\mathrm{BOC}))_{2}$ (Figures S33-S34) and $\mathrm{V}_{6}-\left(\mathrm{CH}_{2} \mathrm{OH}\right)_{2}$ (Figures S30-S31) in presence of CDs is similar to $\mathrm{V}_{6}-\left(\mathrm{NO}_{2}\right)_{2}$, except that the magnitude of the half-wave potentials is less pronounced.

The opposite variation of the standard potential observed with $V_{6}$ $\left(\mathrm{NO}_{2}\right)_{2}$ or $\mathrm{V}_{6}-\left(\mathrm{CH}_{2} \mathrm{CH}_{3}\right)_{2}$ species in the presence of $\alpha-C D$ is accompanied for both cases with a significant decrease of the peak currents (Figure 10A and Figure S26). The positive potential shift indicates that $\alpha-C D$ exhibits stronger affinity for the oneelectron reduced $V_{6}$ form than for the oxidized one. Besides, these observations should be correlated with the thermochemical investigations that showed entropically driven processes for these supramolecular host-guest systems (see Table 1). Electrochemical and ITC studies should pinpoint hydrophobic driven effects that could result from the interplay between the inorganic and organic moieties through the recognition process. Furthermore, upon increasing $\alpha-C D$ content, the redox wave of $\mathrm{V}_{6}-\left(\mathrm{NO}_{2}\right)_{2}$ become more and more asymmetric (Figure $10 \mathrm{C}$ ), featuring by a stronger decreasing of the anodic peak currents compared to that observed for the cathodic one. Such a result suggests that the one-electron transfer leads to the formation of large hybrid aggregates at the electrode interface involving reduced $\mathrm{POV}^{3-}$ species. At last, no significant shift of the halfwave potential of the $\mathrm{V}_{6}-(\mathrm{NH}(\mathrm{BOC}))_{2}$ or $\mathrm{V}_{6}-\left(\mathrm{CH}_{2} \mathrm{OH}\right)_{2} \mathrm{POVs}$ and only a moderate decrease of the peak currents was observed upon addition $\alpha-C D$ (Figures S29 and S32) suggesting that their reduced and oxidized forms behave similarly toward $\alpha-C D$ and form only supramolecular adducts with very weak association constant as proposed by our ITC and NMR studies.

Variation of the observed half-wave potentials can be analyzed quantitatively to estimate the equilibrium constants $\mathrm{K}_{1: 1}$ of hostguest complexes formation involving the POV anions in both oxidized and reduced states. Such an analysis considers the hostguest complexation equilibria given in equations (1) and (2) and the resulting Nernst equation (3).

$$
\begin{aligned}
& \text { (1) }[\mathrm{POV}]^{2-}+\mathrm{CD} \leftrightarrows[\mathrm{POV} @ C D]^{2-} K_{1: 1}^{o x} \\
& \text { (2) }[\mathrm{POV}]^{3-}+C D \leftrightarrows[\mathrm{POV} @ C D]^{3-} \quad K_{1: 1}^{\text {red }} \\
& \text { (3) } E_{1 / 2}=E^{0}+\frac{R T}{F} \ln \frac{\left(1+K_{1: 1}^{o x}[C D]_{e q}\right)}{\left(1+K_{1: 1}^{\text {red }}[C D]_{e q}\right)}
\end{aligned}
$$

where $E^{0}$ is the standard redox potential of CD-free redox system $\left.[\mathrm{POV}]^{2-/[P O V}\right]^{3-}$ and $[C D]_{\text {eq }}$ is the concentration of free cyclodextrin in the equilibrium conditions. Fitting the variation of the apparent $E_{1 / 2}$ using the equation 3 provides fair agreement for all systems except for $\alpha-C D / V_{6}-\left(N_{2}\right)_{2}$ anion For this last systems, the existence 2:1 host-guest complex with the reduced POV (equation 4 ) have to be considered. Consequently the $E_{1 / 2}$ for the system $\alpha-C D / V_{6}-\left(N_{2}\right)_{2}$ was modeled according to equation 5 , and the extracted $K_{2: 1}^{\text {red }}$ value was about $40 \mathrm{M}^{-1}$. The binding constants $K_{1: 1}^{o x}$ and $K_{1: 1}^{\text {red }}$ have been determined by fitting the experimental shift of the apparent potentials (see Figure 10 for $\mathrm{V}_{6}$ $\left(\mathrm{NO}_{2}\right)_{2}$ and Figures S26-S34). Resulting data are reported in the table 1. The binding constants $K_{1: 1}^{o x}$ resulting from the electrochemical experiments appear in good agreement with those determined by ITC and ${ }^{1} \mathrm{H}$ NMR titration measurements (see Table 1)

\section{(4) $[P O V @ C D]^{3-}+C D \leftrightarrows[P O V @ 2 C D]^{3-} K_{2: 1}^{\text {red }}$}

$$
\text { (5) } \quad E_{1 / 2}=E^{0}+\frac{R T}{F} \ln \frac{\left(1+K_{1: 1}^{o x}[C D]_{e q}\right)}{\left(1+K_{1: 1}^{r e d}[C D]_{e q}+K_{1: 1}^{r e d} K_{2: 1}^{r e d}[C D]_{e q}^{2}\right)}
$$

Comparison of $K_{1: 1}^{o x}$ and $K_{1: 1}^{\text {red }}$ for the CD-POV systems is given in Figure 11, and highlights two distinct behaviors. Adding one electron to the hybrid POV significantly decreases its affinity for the largest $C D s$ ( $\gamma-C D$ and $\beta-C D)$, while almost no or even opposite trend is observed with $\alpha-C D$.

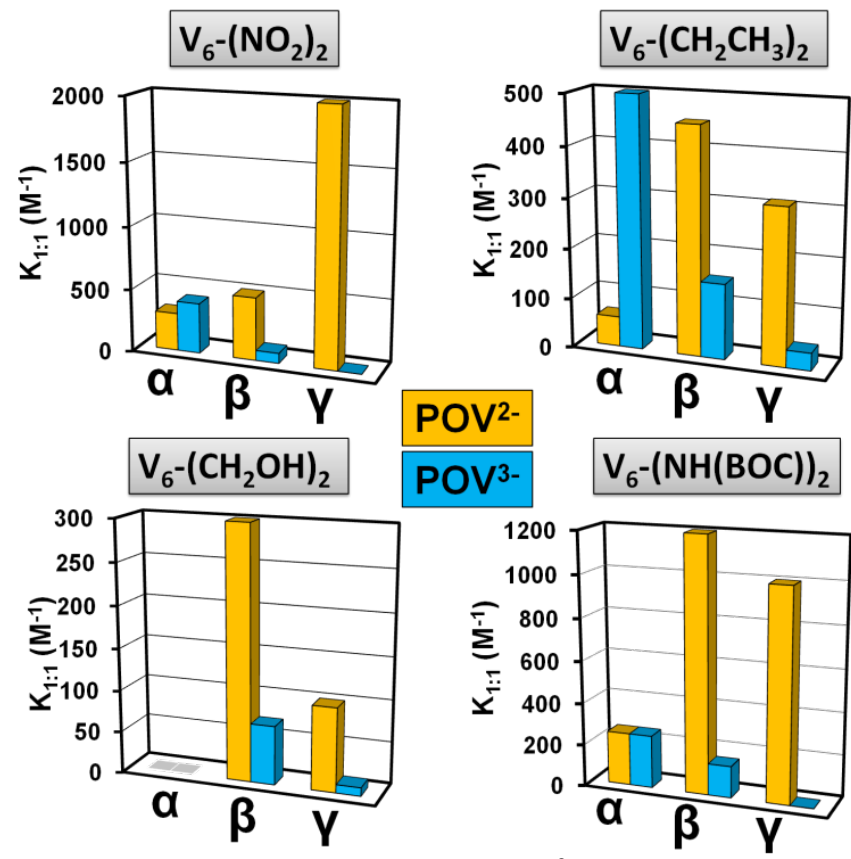

Figure 11. Binding constants of oxidized $\mathrm{POV}^{2-}$ (in yellow) and reduced POV $^{3-}$ (in blue) toward native CDs $\left(\alpha-, \beta-\right.$, and $\left.\gamma^{-C D}\right)$ to form $1: 1$ host-guest complex estimated from electrochemical data, showing i) the decrease of association strength with increasing the global charge of the POV for the largest $\beta$ and $\gamma-C D$, and ii) almost no effect, or even opposite trend with $\alpha$ CD.

Actually, the ability of native CDs to interact with hybrid $\left\{\mathrm{V}_{6} \mathrm{O}_{19}\right\}$ core is highly questionable, since X-ray analysis of the six hostguest structures involving various functional groups and $\alpha-, \beta$ - or $\mathrm{Y}-\mathrm{CD}$ does not evidence any significant attractive interactions. Then, for these hybrid systems containing functional organic patches grafted to the inorganic core $\left\{\mathrm{V}_{6} \mathrm{O}_{19}\right\}$, self-assembly processes should be mainly governed by solvent mediated effects which balance between chaotropic or hydrophobic contributions. Such scenario is reflected by the intricate set of data collected by NMR, ITC and electrochemistry. Depending on the nature of the host-guest system, apparent discrepancies were observed such as i) chemical shift variations, ii) thermochemical fingerprints which featured entropically of enthalpically assisted processes, or iii) positive or negative variations of $E_{1 / 2}$. For instance, the 
chaotropic effect can roughly explain the ratios $K_{1: 1}^{o x} / K_{1: 1}^{\text {red }}>1$ which are more pronounced for $\gamma-C D$ than for $\beta-C D$ probably due to the deeper inclusion complex observed with $\mathrm{Y}-\mathrm{CD}$.

On the contrary, this chaotropic effect does not contribute significantly with the smaller $\alpha-C D$ torus. Actually, as shown by the structural analysis, this $\alpha-C D$ macrocycle interacts exclusively with the functional organic group of the POVs. Consistently, the thermochemical data were rather consistent with hydrophobic effect as the main contributor showing a process mainly governed by entropy. Furthermore, in these specific cases, electrochemical investigations and interpretations lead to the ratios $K_{1: 1}^{o x} / K_{1: 1}^{r e d}<1$ which indicate that the host-guest stability increases as the ionic charge of the POV increases. Such an unusual behavior does not follow the general trend found for processes dominated by the chaotropic effect. Nevertheless, the influence of the reduced-state of the POV reveals that the hydrophobically-driven process is also supported by "pulling forces" including ion-dipole interaction or hydrogen bonding arising from the inorganic part. Our study revealed also that these attractive forces can be amplified through the reduction of POV as observed in the case $\mathrm{V}_{6}-\left(\mathrm{CH}_{2} \mathrm{CH}_{3}\right)_{2}$ or $\mathrm{V}_{6-}$ $\left(\mathrm{NO}_{2}\right)_{2}$ derivatives.

\section{Conclusion}

The self-assembly between three native cyclodextrins $(\alpha-, \beta-$, and $\mathrm{Y}-\mathrm{CD})$ and four hybrid Lindqvist-type POVs $\left[\mathrm{V}_{6} \mathrm{O}_{13}\left(\left(\mathrm{OCH}_{2}\right)_{3} \mathrm{C}\right.\right.$ $\left.\mathrm{R})_{2}\right]^{2-}$ with $\mathrm{R}=\mathrm{CH}_{2} \mathrm{CH}_{3}, \mathrm{NO}_{2}, \mathrm{CH}_{2} \mathrm{OH}$ and $\mathrm{NH}(\mathrm{BOC})$ have been systematically studied both in aqueous solution and in the solidstate. Solution studies using cyclic-voltammetry, NMR methods, and ITC provide a convergent set of data showing oxidized POVs and CDs form host-guest complexes with moderate binding constant. While the nature and size of the functional group of the hybrid POMs influence the strength of the supramolecular association, our data revealed two different behaviors that arise from the operating driving force. For the largest cyclodextrins $(\beta$ and $\mathrm{y}-\mathrm{CD}$ ) enable to encapsulate deeply the inorganic core, the chaotropic effect appears as main driving force. An opposite scenario occurs with $\alpha-C D$ wherein the binding constant of reduced $\mathrm{POV}$ is identical or even slightly higher to those observed for the oxidized form. Such a type of association is mostly consistent with hydrophobically driven process, reinforced by various attractive contributions including hydrogen bonding, iondipole or dispersion forces.

Combining the post-functionalization properties of Lindqvist type hexavanadates ${ }^{[47]}$ and their ability to act as redox-responsive unit, we anticipate that these POVs-based supramolecular systems give opportunities for building innovative molecular machines (rotaxane or molecular shuttles) or smart polymeric materials.

\section{Experimental Section}

Materials. All chemicals were used as received without any further treatment. The sodium salt of $\left[\mathrm{V}_{6} \mathrm{O}_{13}\left(\left(\mathrm{OCH}_{2}\right)_{3} \mathrm{C}-\mathrm{CH}_{2} \mathrm{OH}\right)_{2}\right]^{2-}$ and $\left[\mathrm{V}_{6} \mathrm{O}_{13}\left(\left(\mathrm{OCH}_{2}\right)_{3} \mathrm{C}-\mathrm{NH}(\mathrm{BOC})_{2}\right]^{2-}\right.$ have been synthesized from published procedures. ${ }^{[43,44]}$ The TBA salts of hybrid $V_{6}$ derivatives have been prepared from adapted published procedure. ${ }^{[46]}$ The purity of the compounds has been checked by infrared, ${ }^{1} \mathrm{H}$ and ${ }^{51} \mathrm{~V}$ NMR spectroscopies and by elemental analysis.

Preparation of the water-soluble Lindqvist derivatives.

$\mathrm{Na}_{2}\left[\mathrm{~V}_{6} \mathrm{O}_{13}\left(\left(\mathrm{OCH}_{2}\right)_{3} \mathrm{C}-\mathrm{NO}_{2}\right)_{2}\right] \cdot \mathbf{4} \mathrm{H}_{2} \mathrm{O}$. $500 \mathrm{mg}$ of $\mathrm{TBA}_{2}\left[\mathrm{~V}_{6} \mathrm{O}_{13}\left(\left(\mathrm{OCH}_{2}\right)_{3} \mathrm{C}-\right.\right.$ $\left.\mathrm{NO}_{2}\right)_{2}$ ] $(0.366 \mathrm{mmol})$ was dissolved in $10 \mathrm{ml}$ of acetonitrile. The resulting reddish solution was filtered and then added dropwise to $5 \mathrm{ml}$ of acetonitrile containing $2 \mathrm{~g}$ of sodium perchlorate hydrate $(16 \mathrm{mmol})$. After 30 min under stirring, a dark orange solid was formed. After two hours, the compound $\left.\mathrm{Na}_{2}\left[\mathrm{~V}_{6} \mathrm{O}_{13}\left(\mathrm{OCH}_{2}\right)_{3}-\mathrm{NO}_{2}\right)_{2}\right] \cdot 4 \mathrm{H}_{2} \mathrm{O}(280 \mathrm{mg} ; 0.303 \mathrm{mmol})$ is recovered by centrifugation ( $13000 \mathrm{rpm}$ ), and washed with acetonitrile and diethyl ether. Yield: $85 \%$.

$\mathrm{Na}_{2}\left[\mathbf{V}_{6} \mathrm{O}_{13}\left(\left(\mathrm{OCH}_{2}\right)_{3} \mathbf{C}-\mathrm{CH}_{2} \mathrm{CH}_{3}\right)_{2}\right] \cdot 5 \mathrm{H}_{2} \mathrm{O}$. $3 \mathrm{~g}$ of $\mathrm{TBA}_{2}\left[\mathrm{~V}_{6} \mathrm{O}_{13}\left(\left(\mathrm{OCH}_{2}\right)_{3} \mathrm{C}-\right.\right.$ $\left.\mathrm{CH}_{2} \mathrm{CH}_{3}\right)_{2}$ ] (2.38 mmol) was dissolved in $10 \mathrm{ml}$ of acetonitrile. The resulting reddish solution was filtered and then added dropwise to $5 \mathrm{ml}$ of acetonitrile containing $2 \mathrm{~g}$ of sodium perchlorate hydrate $(16 \mathrm{mmol})$. After 30 min under stirring, a dark orange solid was formed. After two hours, the compound $\mathrm{Na}_{2}\left[\mathrm{~V}_{6} \mathrm{O}_{13}\left(\left(\mathrm{OCH}_{2}\right)_{3} \mathrm{C}-\mathrm{CH}_{2} \mathrm{CH}_{3}\right)_{2}\right] \cdot 5 \mathrm{H}_{2} \mathrm{O}$ (2 g; $\left.2.1 \mathrm{mmol}\right)$ is recovered by centrifugation (13000 rpm), and washed with acetonitrile and diethyl ether. Yield: $90 \%$.

\section{Preparation of host-guest complexes.}

$\mathrm{Na}_{2}\left[\mathrm{~V}_{6} \mathrm{O}_{13}\left(\left(\mathrm{OCH}_{2}\right)_{3} \mathrm{C}-\mathrm{NO}_{2}\right)_{2}\right] \cdot\left[\left(\mathrm{C}_{6} \mathrm{H}_{10} \mathrm{O}_{5}\right)_{6}\right] \cdot 8 \mathrm{H}_{2} \mathrm{O}$ notated $\left\{\mathrm{V}_{6}\left(\mathrm{NO}_{2}\right)_{2}\right\} @ \alpha-$ CD. $\mathrm{Na}_{2}\left[\mathrm{~V}_{6} \mathrm{O}_{13}\left(\left(\mathrm{OCH}_{2}\right)_{3} \mathrm{C}-\mathrm{NO}_{2}\right)_{2}\right] \cdot 4 \mathrm{H}_{2} \mathrm{O}(200 \mathrm{mg} ; 0.215 \mathrm{mmol})$ and $\mathrm{a}-\mathrm{CD}$ (452 mg; $0.433 \mathrm{mmol}$ ) were dissolved in $10 \mathrm{~mL}$ of deionized (DI) water. Reddish crystals are obtained after slow evaporation (7 days) of the reaction mixture. Yield $112 \mathrm{mg}(26 \%$ based on $\mathrm{V})$ of pure crystalline product. Anal. Calcd for $\mathrm{C}_{44} \mathrm{H}_{88} \mathrm{~N}_{2} \mathrm{O}_{61} \mathrm{Na}_{2} \mathrm{~V}_{6}$ : C, $26.8 \%$; $\mathrm{H}, 4.5 \%$; N, $1.4 \%$. Found: $\mathrm{C}, 26.3 ; \mathrm{H}, 4.4 \% ; \mathrm{N}, 1.1 \%$. TGA revealed a weight loss of $7 \%$ from 50 to $200{ }^{\circ} \mathrm{C}$ (the calculated weight loss of $8 \mathrm{H}_{2} \mathrm{O}$ is $7.3 \%$ ).

$\mathrm{Na}_{2}\left[\mathrm{~V}_{6} \mathrm{O}_{13}\left(\left(\mathrm{OCH}_{2}\right)_{3} \mathrm{C}-\mathrm{NO}_{2}\right)_{2}\right] \cdot\left[\left(\mathrm{C}_{6} \mathrm{H}_{10} \mathrm{O}_{5}\right)_{7}\right] \cdot 12 \mathrm{H}_{2} \mathrm{O}$ notated $\left\{\mathrm{V}_{6}\left(\mathrm{NO}_{2}\right)_{2}\right\} @ \beta-$ CD. $\mathrm{Na}_{2}\left[\mathrm{~V}_{6} \mathrm{O}_{13}\left(\left(\mathrm{OCH}_{2}\right)_{3} \mathrm{C}-\mathrm{NO}_{2}\right)_{2}\right] \cdot 4 \mathrm{H}_{2} \mathrm{O}(200 \mathrm{mg} ; 0.215 \mathrm{mmol})$ and $\beta-\mathrm{CD}$ $(510 \mathrm{mg} ; 0.433 \mathrm{mmol})$ were dissolved in $40 \mathrm{~mL}$ of DI water. Reddish crystals are obtained after slow evaporation (7 days) of the reaction mixture. Yield $250 \mathrm{mg}(52 \%$ based on $\mathrm{V})$ of pure crystalline product. $\mathrm{C}_{50} \mathrm{H}_{106} \mathrm{~N}_{2} \mathrm{O}_{70} \mathrm{Na}_{2} \mathrm{~V}_{6}$ : C, $27.2 \% ; \mathrm{H}, 4.8 \% ; \mathrm{N}, 1.3 \%$. Found: C, $29.5 \% ; \mathrm{H}$, $5.2 \%$; N, $0.9 \%$. TGA revealed a weight loss of $10 \%$ from 50 to $200{ }^{\circ} \mathrm{C}$ (the calculated weight loss of $12 \mathrm{H}_{2} \mathrm{O}$ is $9.8 \%$ ).

$\mathrm{Na}_{2}\left[\mathrm{~V}_{6} \mathrm{O}_{13}\left(\left(\mathrm{OCH}_{2}\right)_{3} \mathrm{C}-\mathrm{CH}_{2} \mathrm{OH}\right)_{2}\right] \cdot 2\left[\left(\mathrm{C}_{6} \mathrm{H}_{10} \mathrm{O}_{5}\right)_{7}\right] \cdot 23 \mathrm{H}_{2} \mathrm{O}$ notated $\left\{\mathbf{V}_{6}\left(\mathrm{CH}_{2} \mathrm{OH}\right)_{2}\right\} @ 2 \beta-C D . \mathrm{Na}_{2}\left[\mathrm{~V}_{6} \mathrm{O}_{13}\left(\left(\mathrm{OCH}_{2}\right)_{3} \mathrm{C}-\mathrm{CH}_{2} \mathrm{OH}\right)_{2}\right] \cdot 4 \mathrm{H}_{2} \mathrm{O}(500 \mathrm{mg} ;$ $0.53 \mathrm{mmol})$ and $\beta-C D(1.214 \mathrm{~g} ; 1 \mathrm{mmol})$ were dissolved in $100 \mathrm{~mL}$ of DI water. The solution was heated at $50^{\circ} \mathrm{C}$ during 1 hour. Crystals of $\left\{\mathbf{V}_{6}\left(\mathrm{CH}_{2} \mathrm{OH}\right)_{2}\right\} @ 2 \beta-C D$ were obtained by slow ethanol vapor diffusion into aqueous solution. Reddish crystals are obtained after 2 days. Yield $1.32 \mathrm{~g}$ $(71 \%$ based on $\mathrm{V})$ of pure crystalline product. Anal. Calcd for $\mathrm{C}_{94} \mathrm{H}_{204} \mathrm{O}_{114} \mathrm{Na}_{2} \mathrm{~V}_{6}$ : C, 32.9\%; $\mathrm{H}, 6.0 \%$. Found: C, 32.2\%; H, 5.9\%. TGA revealed a weight loss of $12 \%$ from 50 to $200{ }^{\circ} \mathrm{C}$ (the calculated weight loss of $23 \mathrm{H}_{2} \mathrm{O}$ is $11.8 \%$ ).

$\mathrm{Na}_{2}\left[\mathrm{~V}_{6} \mathrm{O}_{13}\left(\left(\mathrm{OCH}_{2}\right)_{3} \mathrm{C}-\mathrm{NH}\left(\mathrm{CO}_{2} \mathrm{C}\left(\mathrm{CH}_{3}\right)_{4}\right)_{2}\right] \cdot 2\left[\left(\mathrm{C}_{6} \mathrm{H}_{10} \mathrm{O}_{5}\right)_{7}\right] \cdot 2 \mathrm{H}_{2} \mathrm{O}\right.$ notated $\left\{\mathbf{V}_{6}(\mathbf{N H}(\mathrm{BOC}))_{2}\right\} @ 2 \beta-C D . \mathrm{Na}_{2}\left[\mathrm{~V}_{6} \mathrm{O}_{13}\left(\left(\mathrm{OCH}_{2}\right)_{3} \mathrm{C}-\mathrm{H}(\mathrm{BOC})\right)_{2}\right] \cdot 13.5 \mathrm{H}_{2} \mathrm{O}(333$ $\mathrm{mg} ; 0.27 \mathrm{mmol})$ and $\beta-C D(613 \mathrm{mg} ; 0.54 \mathrm{mmol})$ were dissolved in $10 \mathrm{~mL}$ of DI water. The solution was heated at $50^{\circ} \mathrm{C}$ during 1 hour. Reddish crystals are obtained after slow evaporation (7 days) of the reaction mixture. Yield $212 \mathrm{mg} \mathrm{(21 \%} \mathrm{based} \mathrm{on} \mathrm{V}$ ) of pure crystalline product. Calcd for $\mathrm{C}_{104} \mathrm{H}_{218} \mathrm{~N}_{2} \mathrm{O}_{113} \mathrm{Na}_{2} \mathrm{~V}_{6}$ : C, 34.2\%; $\mathrm{H}, 6.0 \%$; N, 0.8\%. Found: C, 31.9\%; $\mathrm{H}, 5.9 \%$; N $0.8 \%$. TGA revealed a weight loss of $10 \%$ from 50 to $200{ }^{\circ} \mathrm{C}$ (the calculated weight loss of $20 \mathrm{H}_{2} \mathrm{O}$ is $9.8 \%$ ).

$\mathrm{Na}_{2}\left[\mathrm{~V}_{6} \mathrm{O}_{13}\left(\left(\mathrm{OCH}_{2}\right)_{3} \mathrm{C}-\mathrm{NO}_{2}\right)_{2}\right] \cdot 2\left[\left(\mathrm{C}_{6} \mathrm{H}_{10} \mathrm{O}_{5}\right)_{8}\right] \cdot 21 \mathrm{H}_{2} \mathrm{O}$ notated $\left\{\mathrm{V}_{6}\left(\mathrm{NO}_{2}\right)_{2}\right\} @ 2 \mathrm{Y}-\mathrm{CD} . \mathrm{Na}_{2}\left[\mathrm{~V}_{6} \mathrm{O}_{13}\left(\left(\mathrm{OCH}_{2}\right)_{3} \mathrm{C}-\mathrm{NO}_{2}\right)_{2}\right] \cdot 4 \mathrm{H}_{2} \mathrm{O}(200 \mathrm{mg} ; 0.216$ $\mathrm{mmol})$ and $\mathrm{Y}-\mathrm{CD}(620 \mathrm{mg} ; 0.433 \mathrm{mmol})$ were dissolved in $10 \mathrm{~mL}$ of DI water. Reddish crystals are obtained after slow evaporation (7 days) of the reaction mixture. Yield $160 \mathrm{mg}(19 \%$ based on $\mathrm{V})$ of pure crystalline product. Anal. Calcd for $\mathrm{C}_{104} \mathrm{H}_{214} \mathrm{~N}_{2} \mathrm{O}_{124} \mathrm{Na}_{2} \mathrm{~V}_{6}$ : C, 32.6\%; $\mathrm{H}, 5.6 \% ; \mathrm{N}$, $0.7 \%$. Found: $\mathrm{C}, 33.4 \% ; \mathrm{H}, 5.5 \% ; \mathrm{N}, 0.8 \%$. TGA revealed a weight loss of $10 \%$ from 50 to $200{ }^{\circ} \mathrm{C}$ (the calculated weight loss of $21 \mathrm{H}_{2} \mathrm{O}$ is $9.9 \%$ ).

$\mathrm{Na}_{2}\left[\mathrm{~V}_{6} \mathrm{O}_{13}\left(\left(\mathrm{OCH}_{2}\right)_{3} \mathrm{C}-\mathrm{CH}_{2} \mathrm{OH}\right)_{2}\right] \cdot 2\left[\left(\mathrm{C}_{6} \mathrm{H}_{10} \mathrm{O}_{5}\right)_{8}\right] \cdot 24 \mathrm{H}_{2} \mathrm{O}$ notated $\left\{\mathrm{V}_{6}\left(\mathrm{CH}_{2} \mathrm{OH}\right)_{2}\right\} @ 2 \mathrm{y}-\mathrm{CD}$. Na $2\left[\mathrm{~V}_{6} \mathrm{O}_{13}\left(\left(\mathrm{OCH}_{2}\right)_{3} \mathrm{C}-\mathrm{CH}_{2} \mathrm{OH}\right)_{2}\right] \cdot 4 \mathrm{H}_{2} \mathrm{O}(500 \mathrm{mg}$; $0.53 \mathrm{mmol})$ and $y-C D(1.53 \mathrm{~g} ; 1 \mathrm{mmol})$ were dissolved in $25 \mathrm{~mL}$ of DI water. Crystals of $\left\{\mathrm{V}_{6}\left(\mathrm{CH}_{2} \mathrm{OH}\right)_{2}\right\} @ 2 \mathrm{Y}-\mathrm{CD}$ were obtained by slow ethanol vapor 
diffusion into aqueous solution after 9 days, and then were collected, washed with water/ethanol mixture, and dried on air. Yield $1.9 \mathrm{~g}(93 \%$ based on $\mathrm{V}$ ) of pure crystalline product. Anal. Calcd for $\mathrm{C}_{106} \mathrm{H}_{226} \mathrm{O}_{125} \mathrm{Na}_{2} \mathrm{~V}_{6}$ : C, 33.0\%; H, 5.9\%. Found: C, 32.69\%; H, 6.0\%. TGA revealed a weight loss of $11.4 \%$ from 50 to $200{ }^{\circ} \mathrm{C}$ (the calculated weight loss of $24 \mathrm{H}_{2} \mathrm{O}$ is $11.2 \%)$.

Single-Crystal X-ray Diffraction. Crystals were selected under polarizing optical microscope and glued in paratone oil. X-ray intensity data for the supramolecular compounds $\left\{\mathbf{V}_{6}\left(\mathrm{NO}_{2}\right)_{2}\right\} @ \alpha-\mathbf{C D}, \quad\left\{\mathbf{V}_{6}\left(\mathrm{NO}_{2}\right)_{2}\right\} @ \beta-\mathbf{C D}$, $\left\{\mathrm{V}_{6}\left(\mathrm{CH}_{2} \mathrm{OH}\right)_{2}\right\} @ 2 \beta-\mathrm{CD},\left\{\mathrm{V}_{6}(\mathrm{NH}(\mathrm{BOC}))_{2}\right\} \mathbf{2}_{2} \beta-\mathrm{CD}$, and $\left\{\mathrm{V}_{6}\left(\mathrm{NO}_{2}\right)_{2}\right\} @ 2 \gamma-$ CD were collected at low temperature ( $T=220$ (2) or 200(2) K) on a Bruker D8 VENTURE diffractometer equipped with a PHOTON III C14 using a high brilliance $\mathrm{I} \mu \mathrm{S}$ microfocus $\mathrm{X}$-ray Mo Ka monochromatized radiation $(\lambda$ $=0.71073 \AA$ ). For $\left\{\mathbf{V}_{6}\left(\mathbf{C H}_{2} \mathrm{OH}\right)_{2}\right\} @ 2 \mathbf{y}-\mathbf{C D}$, lintensity data collection was carried out he using X-Ray synchrotron beam line $(\lambda=0.72931 \AA)$ at PROXIMA2 in SOLEIL (Gif-sur-Yvette, CEDEX, France). Data reduction was accomplished using SAINT V7.53a. The substantial redundancy in data allowed a semi-empirical absorption correction (SADABS V2.10) to be applied, on the basis of multiple measurements of equivalent reflections. Using Olex ${ }^{48}$, the structure was solved with the ShelXT ${ }^{49}$ structure solution program using Intrinsic Phasing and refined with the ShelXL ${ }^{50}$ refinement package using Least Squares minimization. The remaining non-hydrogen atoms were located from Fourier differences and were refined with anisotropic thermal parameters. Positions of the hydrogen atoms belonging to cyclodextrins or to the hybrid $V_{6}$-based derivatives were calculated and refined isotropically using the gliding mode. Crystallographic data for single-crystal $\mathrm{X}$-ray diffraction studies are summarized in Table S1-6. These data can be obtained free of charge from The Cambridge Crystallographic Data Centre via https://www.ccdc.cam.ac.uk/structures-beta/. Deposit number: 2091553 2091554, 2091555, 2091556, 2091557 and 2091558 for $\left\{\mathbf{V}_{6}\left(\mathbf{N O}_{2}\right)_{2}\right\} @ \alpha-$ $\mathrm{CD},\left\{\mathrm{V}_{6}\left(\mathrm{NO}_{2}\right)_{2}\right\} @ \beta-\mathrm{CD},\left\{\mathrm{V}_{6}\left(\mathrm{CH}_{2} \mathrm{OH}\right)_{2}\right\} @ 2 \beta-\mathrm{CD},\left\{\mathrm{V}_{6}(\mathrm{NH}(\mathrm{BOC}))_{2}\right\}$ @2 $\beta-\mathrm{CD}$ $\left\{\mathrm{V}_{6}\left(\mathrm{NO}_{2}\right)_{2}\right\} @ 2 \mathrm{y}-\mathrm{CD}$ and $\left.\mathbf{V}_{6}\left(\mathrm{CH}_{2} \mathrm{OH}\right)_{2}\right\}$ @2 $\mathrm{y}-\mathrm{CD}$, respectively.

Infrared Spectroscopy. Fourier transform infrared (FT-IR) spectra were recorded on a 6700 FT-IR Nicolet spectrophotometer, using diamond attenuated total reflectance (ATR) technique. The spectra were recorded on new compounds in the range of $400-4000 \mathrm{~cm}^{-1}$ and are reported in Supporting Information (see Figure S20-25).

Isothermal titration calorimetry (ITC). Formation constants and inclusion enthalpies were simultaneously determined for each system by the use of an isothermal calorimeter (ITC200, MicroCal Inc.), at 298K. Degassed water solutions were used in both cell $(202.8 \mu \mathrm{L}$, filled with 0.5 $\mathrm{mM} \mathrm{V} 6-(\mathrm{R})_{2}$ solution) and syringe $(40 \mu \mathrm{L}$, filled with $5 \mathrm{mM} \mathrm{CD}$ solution). Titrations involved 11 aliquots of $3.5 \mu \mathrm{L}$ of the syringe solution, delivered over $7 \mathrm{~s}$ for each injection. Time interval between two consecutive injections and agitation speed were set to $75 \mathrm{~s}$ and $1000 \mathrm{rpm}$, respectively. The resulting heat flow was recorded as a function of time. The heat of dilution was eliminated from each titration by subtracting the raw signal obtained for the corresponding blank titrations. The peak area following each addition was obtained by integration of the resulting signal and was expressed as the heat effect per injection. Thermodynamic parameters were determined by nonlinear regression analysis of the binding isotherms, using a dedicated homemade program. ${ }^{[48]}$

Nuclear Magnetic Resonance. All NMR spectra were measured in $\mathrm{D}_{2} \mathrm{O}$ at $26{ }^{\circ} \mathrm{C} .{ }^{1} \mathrm{H}$ and ${ }^{51} \mathrm{~V}$ NMR spectra were recorded on a Bruker Avance 400 spectrometer equipped with a $\mathrm{BBI}$ probehead. Translational diffusion measurements were performed using Bruker's "ledbpgs2s" stimulated echo DOSY pulse sequence including bipolar and spoil gradients. Apparent diffusion coefficients were obtained using an adapted algorithm based on the inverse Laplace transform and maximum entropy. $2 \mathrm{D}{ }^{1} \mathrm{H}-{ }^{1} \mathrm{H}$ ROESY spectra were carried out on some selected samples using standard phase sensitive pulse sequences in States mode and $300 \mathrm{~ms}$ mixing time. Chemical shifts are relative to standards: tetramethylsilane $\left(\mathrm{CDCl}_{3}, 1 \mathrm{wt} \%\right)$ for ${ }^{1} \mathrm{H}$ and to $\mathrm{VOCl}_{3}\left(\mathrm{C}_{6} \mathrm{D}_{6}, 90 \% \mathrm{VOCl}_{3}\right)$ for ${ }^{51} \mathrm{~V}$. The ${ }^{1} \mathrm{H}$ and ${ }^{51} \mathrm{~V}$ NMR spectra of the six new compounds are reported in Supporting Information (see Figure S17-18).

Electrochemistry. Cyclic voltammetric (CV) experiments were performed with a compact PalmSens4 driven by a computer using PSTrace software. Measurements were performed at room temperature in a singlecompartment micro-cell. A glassy carbon (GC) electrode with a diameter of $2 \mathrm{~mm}( \pm 0.2 \mathrm{~mm}$ ) was used as the working electrode. The auxiliary electrode was a Pt plate, and potentials are quoted against an $\mathrm{Ag} / \mathrm{AgCl}$ reference electrode. The solutions were deaerated thoroughly for at least $5 \mathrm{~min}$ with pure argon. The solution was prepared by dissolving $50 \mu \mathrm{ml}$ of hybrid POVs in $50 \mathrm{~mL}$ of aqueous solution of $\mathrm{Na}_{2} \mathrm{SO}_{4}(0.5 \mathrm{M} ; \mathrm{pH}=6)$. Then different amounts of native cyclodextrins were added under vigorous stirring.

\section{Acknowledgements}

Authors gratefully acknowledge financial support from LabEx CHARMMMAT (grant number ANR-11-LBX-0039). This work was also supported by i) University of Versailles Saint Quentin, ii) CNRS (MOMENTUM project), iii) Région lle de France through DIM Nano K. I. F. B. thanks the Embassy of Ivory Coast in France for his PhD grant.

Keywords: Lindqvist $•$ Vanadates $\cdot$ Cyclodextrin $\cdot$ Host-guest chemistry $\cdot$ XRD structure

\section{References}

[1] M. Pope, Heteropoly and Isopoly Oxometalates, Springer-Verlag, Berlin Heidelberg, 1983

[2] M. Stuckart, K. Y. Monakhov, Chem. Sci. 2019, 10, 4364-4376.

[3] G. Izzet, M. Ménand, B. Matt, S. Renaudineau, L.-M. Chamoreau, M. Sollogoub, A. Proust, Angew. Chem. Int. Ed. 2012, 51, 487-490.

[4] P. Yang, W. Zhao, A. Shkurenko, Y. Belmabkhout, M. Eddaoudi, X. Dong, H. N. Alshareef, N. M. Khashab, J. Am. Chem. Soc. 2019, 141, 1847-1851.

[5] Y. Fan, Y. Zhang, Q. Jia, J. Cao, W. Wu, Mass Spectrom. Lett. 2015, 6, 13-16.

[6] L. Ni, H. Li, H. Xu, C. Shen, R. Liu, J. Xie, F. Zhang, C. Chen, H. Zhao, T. Zuo, G. Diao, ACS Appl. Mater. Interfaces 2019, 11, 38708-38718.

[7] W. Guan, G. Wang, J. Ding, B. Li, L. Wu, Chem. Commun. 2019, 55, 10788-10791.

[8] H. Li, F. Jiang, G. Zhang, B. Li, L. Wu, Dalton Trans. 2019, 48, 51685175 .

[9] L. Leclercq, R. Company, A. Mühlbauer, A. Mouret, J.-M. Aubry, V. Nardello-Rataj, ChemSusChem 2013, 6, 1533-1540.

[10] L. Yue, H. Ai, Y. Yang, W. Lu, L. Wu, Chem. Commun. 2013, 49, 97709772.

[11] B. Zhang, W. Guan, S. Zhang, B. Li, L. Wu, Chem. Commun. 2016, 52, 5308-5311.

[12] B. Zhang, L. Yue, Y. Wang, Y. Yang, L. Wu, Chem. Commun. 2014, 50, 10823-10826.

[13] M. Stuckart, N. V. Izarova, J. van Leusen, A. Smekhova, C. SchmitzAntoniak, H. Bamberger, J. van Slageren, B. Santiago-Schübel, P. Kögerler, Chem. Eur. J. 2018, 24, 17767-17778.

[14] Y. Wu, R. Shi, Y.-L. Wu, J. M. Holcroft, Z. Liu, M. Frasconi, M. R. Wasielewski, H. Li, J. F. Stoddart, J. Am. Chem. Soc. 2015, 137, 41114118.

[15] C. Falaise, M. A. Moussawi, S. Floquet, P. A. Abramov, M. N. Sokolov, M. Haouas, E. Cadot, J. Am. Chem. Soc. 2018, 140, 11198-11201.

[16] M. A. Moussawi, M. Haouas, S. Floquet, W. E. Shepard, P. A. Abramov, M. N. Sokolov, V. P. Fedin, S. Cordier, A. Ponchel, E. Monflier, J. Marrot, E. Cadot, J. Am. Chem. Soc. 2017, 139, 14376-14379.

[17] M. A. Moussawi, N. Leclerc-Laronze, S. Floquet, P. A. Abramov, M. N. Sokolov, S. Cordier, A. Ponchel, E. Monflier, H. Bricout, D. Landy, M Haouas, J. Marrot, E. Cadot, J. Am. Chem. Soc. 2017, 139, 12793-12803.

[18] C. Falaise, S. Khlifi, P. Bauduin, P. Schmid, W. Shepard, A. A. Ivanov, M. N. Sokolov, M. A. Shestopalov, P. A. Abramov, S. Cordier, J. Marrot, M. Haouas, E. Cadot, Angew. Chem. Int. Ed. 2021, 60, 14146-14153. 
[19] S. Yao, C. Falaise, A. A. Ivanov, N. Leclerc, M. Hohenschutz, M. Haouas, D. Landy, M. A. Shestopalov, P. Bauduin, E. Cadot, Inorg. Chem. Front. 2021, 8, 12-25.

[20] S. Yao, C. Falaise, S. Khlifi, N. Leclerc, M. Haouas, D. Landy, E. Cadot, Inorg. Chem. 2021, 60, 7433-7441.

[21] K. I. Assaf, M. S. Ural, F. Pan, T. Georgiev, S. Simova, K. Rissanen, D. Gabel, W. M. Nau, Angew. Chem. Int. Ed. 2015, 54, 6852-6856.

[22] K. I. Assaf, W. M. Nau, Angew. Chem. Int. Ed. 2018, 57, 13968-13981.

[23] K. I. Assaf, B. Begaj, A. Frank, M. Nilam, A. S. Mougharbel, U. Kortz, J. Nekvinda, B. Grüner, D. Gabel, W. M. Nau, J. Org. Chem. 2019, 84, 11790-11798.

[24] C. Falaise, A. A. Ivanov, Y. Molard, M. A. Cortes, M. A. Shestopalov, M. Haouas, E. Cadot, S. Cordier, Mater. Horiz. 2020, 7, 2399-2406.

[25] A. A. Ivanov, C. Falaise, D. Landy, M. Haouas, Y. V. Mironov, M. A. Shestopalov, E. Cadot, Chem. Commun. 2019, 55, 9951-9954.

[26] A. A. Ivanov, C. Falaise, P. A. Abramov, M. A. Shestopalov, K. Kirakci, K. Lang, M. A. Moussawi, M. N. Sokolov, N. G. Naumov, S. Floquet, D. Landy, M. Haouas, K. A. Brylev, Y. V. Mironov, Y. Molard, S. Cordier, E. Cadot, Chem. Eur. J. 2018, 24, 13467-13478.

[27] A. A. Ivanov, C. Falaise, K. Laouer, F. Hache, P. Changenet, Y. V. Mironov, D. Landy, Y. Molard, S. Cordier, M. A. Shestopalov, M. Haouas, E. Cadot, Inorg. Chem. 2019, 58, 13184-13194.

[28] A. A. Ivanov, C. Falaise, A. A. Shmakova, N. Leclerc, S. Cordier, Y. Molard, Y. V. Mironov, M. A. Shestopalov, P. A. Abramov, M. N. Sokolov, M. Haouas, E. Cadot, Inorg. Chem. 2020, 59, 11396-11406.

[29] L. E. VanGelder, A. M. Kosswattaarachchi, P. L. Forrestel, T. R. Cook, E. M. Matson, Chem. Sci. 2018, 9, 1692-1699.

[30] B. E. Petel, E. M. Matson, Chem. Commun. 2020, 56, 13477-13490.

[31] M. Anjass, G. A. Lowe, C. Streb, Angew. Chem. Int. Ed. 2021, 60, 75227532.

[32] S. Greiner, M. H. Anjass, M. Fichtner, C. Streb, Inorg. Chem. Front 2019, 7, 134-139.

[33] B. Schwarz, J. Forster, M. K. Goetz, D. Yücel, C. Berger, T. Jacob, C. Streb, Angew. Chem. Int. Ed. 2016, 55, 6329-6333.

[34] O. Linnenberg, M. Moors, A. Notario-Estévez, X. López, C. de Graaf, S. Peter, C. Baeumer, R. Waser, K. Y. Monakhov, J. Am. Chem. Soc. 2018, 140, 16635-16640.

[35] M. Stuckart, K. Y. Monakhov, in Encyclopedia of Inorganic and Bioinorganic Chemistry, American Cancer Society, 2018, pp. 1-19.

[36] A. Al-Qatati, F. L. Fontes, B. George Barisas, D. Zhang, D. A. Roess, D. C. Crans, Dalton Trans. 2013, 42, 11912-11920.

[37] D. Althumairy, K. Postal, B. George Barisas, G. G. Nunes, D. A. Roess, D. C. Crans, Metallomics 2020, 12, 1044-1061.

[38] A. Bijelic, M. Aureliano, A. Rompel, Angew. Chem. Int. Ed. 2019, 58, 2980-2999.

[39] M. Aureliano, G. Fraqueza, C. A. Ohlin, Dalton Trans. 2013, 42, 11770 11777.

[40] G. Fraqueza, C. A. Ohlin, W. H. Casey, M. Aureliano, J. Inorg. Biochem. 2012, 107, 82-89.

[41] G. Fraqueza, L. A. E. B. de Carvalho, M. P. M. Marques, L. Maia, C. A. Ohlin, W. H. Casey, M. Aureliano, Dalton Trans. 2012, 41, 12749 12758 .

[42] A. C. F. Ribeiro, V. M. M. Lobo, A. J. M. Valente, S. M. N. Simões, A J. F. N. Sobral, M. L. Ramos, H. D. Burrows, Polyhedron 2006, 25, 35813587.

[43] A. Müller, J. Meyer, H. Bögge, A. Stammler, A. Botar, Z. Anorg. Allg. Chem. 1995, 621, 1818-1831.

[44] I. F. Bamba, C. Falaise, G. K. Gbassi, P. Atheba, M. Haouas, E. Cadot, J. Coord. Chem. 2020, 0, 1-12.

[45] M. V. Rekharsky, Y. Inoue, Chem. Rev. 1998, 98, 1875-1918.

[46] Q. Chen, D. P. Goshorn, C. P. Scholes, X. L. Tan, J. Zubieta, J. Am. Chem. Soc. 1992, 114, 4667-4681.

[47] A. V. Anyushin, A. Kondinski, T. N. Parac-Vogt, Chem. Soc. Rev. 2020 49, 382-432.

[48] E. Bertaut, D. Landy, Beilstein J. Org. Chem. 2014, 10, 2630-2641. 


\section{Entry for the Table of Contents}

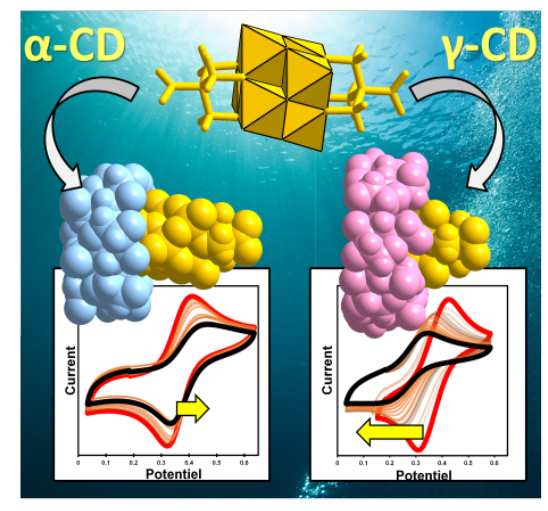

Hydrophobic or chaotropic effect? Hybrid Lindqvist-type polyoxovanadates self-assemble with cyclodextrins ( $\alpha-, \beta-$, and $\left.\gamma^{-}\right)$in water to form a wide variety of host-guest complexes. Such a supramolecular process originates from the ability of the CD host to desolvate the hybrid guests, but the nature of this solvent effect depends on the cyclodextrins, inducing direct consequences on redox properties of the guest.

Institute and/or researcher Twitter usernames: @ILV_UMR8180 ; @FalaiseClement 